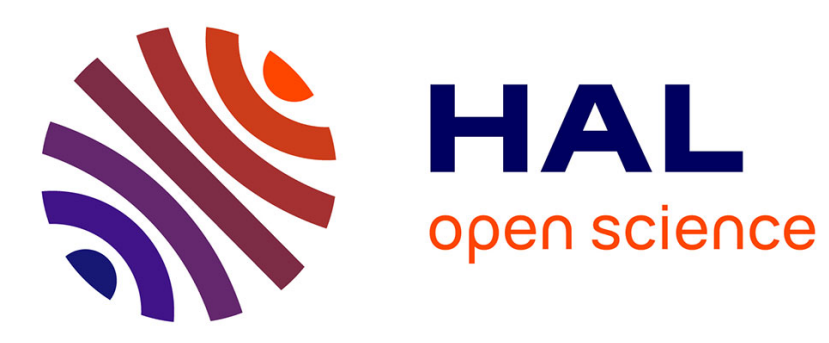

\title{
Family firms and the cost of borrowing empirical evidence from East Asia
}

Christophe J. Godlewski, Hong Nhung Le

\section{To cite this version:}

Christophe J. Godlewski, Hong Nhung Le. Family firms and the cost of borrowing empirical evidence from East Asia. Research in International Business and Finance, 2021, pp.101570. 10.1016/j.ribaf.2021.101570 . hal-03431834

\section{HAL Id: hal-03431834 \\ https://hal.science/hal-03431834}

Submitted on 16 Nov 2021

HAL is a multi-disciplinary open access archive for the deposit and dissemination of scientific research documents, whether they are published or not. The documents may come from teaching and research institutions in France or abroad, or from public or private research centers.
L'archive ouverte pluridisciplinaire HAL, est destinée au dépôt et à la diffusion de documents scientifiques de niveau recherche, publiés ou non, émanant des établissements d'enseignement et de recherche français ou étrangers, des laboratoires publics ou privés. 
Laboratoire de Recherche en Gestion \& Economie

\section{Working Paper}

\section{1-06}

\section{FAMILY FIRMS AND THE COST OF BORROWING \\ EMPIRICAL EVIDENCE FROM EAST ASIA}

Christophe J. Godlewski \& Nhung Hong Le

October 2021

Université de Strasbourg

Pôle Européen de Gestion et

d'Economie

61 avenue de la Forêt Noire

67085 Strasbourg Cedex http://large.em-strasbourg.eu/ 


\title{
FAMILY FIRMS AND THE COST OF BORROWING EMPIRICAL EVIDENCE FROM EAST ASIA
}

\author{
Christophe J. Godlewski ${ }^{1}$ \\ University of Strasbourg \& EM Strasbourg Business School \\ Nhung Hong Le $\mathrm{L}^{2}$ \\ International University - Vietnam National University \& University of Strasbourg
}

October 2021

\begin{abstract}
We investigate the impact of family firms on the cost of borrowing in East Asia. We find consistent evidence that family firms pay significantly higher loan spreads than nonfamily firms. This effect is stronger in environments with weaker investor protection. Furthermore, covenants help reduce the cost of debt while collateral is embedded in relatively riskier borrowers. We also find that small, highly leveraged borrowers pay higher loan spreads, while they are lower for firms with more tangible assets and lower probability of default risk. Our results survive several robustness checks related to family firm classification and endogeneity issues.
\end{abstract}

JEL classification: G21, G32.

Keywords: Family firm, loan spread, East Asia.

${ }^{1}$ Tel.: +33 368852121. E-mail: godlewski@unistra.fr

${ }^{2}$ Tel.: +84 913318091. E-mail: lhnhung@hcmiu.edu.vn 


\section{INTRODUCTION}

While extend literature has focused on the effects of family control on firms from the perspective of shareholders (Dawson et al., 2018, Villalonga and Amit, 2006) ${ }^{3}$, the influence of family control from the perspective of creditors is scarce (Murro and Peruzzi, 2019, Aslan and Kumar, 2012), despite the fact that financial institutions provide the majority of external financing in most economies across the world (Demirgüç-Kunt and Levine, 2004). This is even more important in East Asia where banking plays an important role across Asia's financial systems. It is reported that bank financing covers by far the largest share of corporate financing in emerging Asia, accounting for $123.6 \%$ of corporate financing (as a percentage of GDP) in the region in 2018. Asia's cross-border bank credit continues to soar from $\$ 849$ billion in 2013 to $\$ 1,029$ billion in 2018 (The Asian Economic Integration Report, 2019-2020).

Theories provide competing predictions on the relationship between family ownership and the cost of debt. On the one hand, resource - based view which considers family as a source of competitive advantage, argues that firm - creditor agency conflict is less severe in family firms. Family firms with long-term survivorship and reputational concerns are less likely to strategically default. Founding families with large block holdings and undiversified investments have a lower preference for risky high-growth investments (Carney, 2005), which is in alignment with creditors' interests (Anderson et al., 2012). In addition, family firms are able to nurture long - lasting relationships with banks (Cucculelli et al., 2019, Ellul et al., 2007), which mitigates asymmetric information issues. These lead to a lower cost of debt for family firms.

\footnotetext{
${ }^{3}$ Along with empirical literature dealing with the impact of family on dividend policy (Briano-Turrent et al., 2020) or corporate governance mechanisms such as board turnover (Gonzalez et al., 2019).
} 
On the other hand, cultural theory suggests that strong family values may generate disadvantages for family firms in the borrower-creditor relationship. Family owners may prefer to maximize their utility rather than firm value. The entrenchment effect from family management may lead to higher opacity (Murro and Peruzzi, 2019), which increases information asymmetry problems. Furthermore, a high ownership concentration in family firms may lead to increased expropriation risk of minor shareholders. These are negatively perceived by creditors (Aslan and Kumar, 2012). Hence, family firms may suffer a higher cost of debt relative to nonfamily firms.

Empirical studies show that the relationship between the cost of debt and family ownership depends on various settings, at the country level and/or institutional level. Lin et al. (2011) who study the cost of borrowing in 22 counties argue that excess control rights in family firms, which facilitates moral hazard, will increase monitoring costs and credit risk. They find that family firms suffer a higher cost of debt compared to nonfamily firms. Similarly, Gao et al. (2020) find that Chinese listed family firms have higher bond-yield spread due to risk of expropriation and financial reporting quality. Boubakri and Ghouma (2010) provide similar results in an international context. In contrast, Anderson et al. (2003) find that family firms in S\&P 500 are associated with a lower cost of debt since family firms concerns about survival and reputation help reduce agency conflicts with creditors. In line with Anderson et al. (2003), Swanpitak et al. (2020) find that family firms in Thailand have a lower cost of debt compared to nonfamily firms, which is a result of fostering and nurturing the strong and trustworthy relationships with creditors. It is argued that the relationship between the cost of debt and family ownership may depend on the institutional setting.

East Asia is an important arena for considering the context for family business for several reasons. First, family firms occupy the commanding heights of capitalism in East Asia, the world's 
most dynamic and emerging region. Over half of the largest business groups in many East Asian countries are controlled by families; top 15 families control assets worth approximately $84 \%$ of GDP in Hong Kong, with corresponding figures of 76\% in Malaysia, 48\% in Singapore and 47\% in the Philippines (The Economist 2015). In Korea, top 20 families control the huge conglomerates or chaebols that account for $60 \%$ of the country's stock market value.

Second, East Asia is a more family - oriented region than West, with a more active role of family in business. Scholars have long-portrayed that East Asia is peculiar to Europe and North America with extended family co-residence and "strong" family ties (Goode, 1963, Reher, 2004). Carney and Gedajlovic (2002) show a compelling case that organizing principles in the Asian region differ significantly from "orthodox Western practice”. In addition, the Asian business landscape is also characterized by the informal nature of stakeholder relations, which is different from Western business view.

Finally, the contextual environment in East Asia is unique for studying family firms. The region is particularly revealing of a convergence - divergence ambiguity (Steier, 2009). Whilst globalizing, it is still persisting in unique institutional contexts. While generally the formal institutional environment in this region is weak and arm-length market driven factors are deficient, countries within the region are at varying stages of institutional development, leading the role of family in voiding the shortcomings of markets. In addition, while there are some similarities across nations within the region, each country possesses its own unique history, culture, and sociopolitical environment (Sharma and Chua, 2013). Especially, religions which shape cultural values and influence individual behaviors, are diverse in this region (Dinh and Calabrò, 2019). 
Indeed, some specific features of family firms can be fostered stronger while others mitigated depending on the institutional environment in which family firms operate. Studying family firms in cross East Asian countries in the context of both formal and informal institutions contributes to a better understanding of family firms in East Asia. In weak legal and institutional environments where commitment mechanisms for avoiding moral hazard problems are less credible, we expect that the family firms characteristics such as preference for private interest of control (Burkart et al., 2003), incentives to expropriate minority shareholders (Djankov et al., 2008, Jensen and Meckling, 1976, Claessens et al., 2002), and management entrenchment (Chen et al., 2014) may be amplified.

Besides, given that religion in East Asia is very influential within society (Cohen and Varnum, 2016), we expect that the risk of opportunistic behaviors caused by family may be reduced due to the influence of religiosity. Religiosity can directly enhance business ethics and constrain opportunistic behaviors in business contracting and financial reporting (McGuire et al., 2012). Chen et al. (2016) show that religious social norms represent a mechanism for reducing costly agency conflicts, leading to a lower cost of debt. Motivated by Dinh and Calabrò (2019), we take into account religion in investigating the impact of family ownership on the cost of debt.

We focus on the impact of family involvement on the cost of debt in East Asia including South Korea, Taiwan, Indonesia, Malaysia, Singapore, Philippines, Thailand, and Hong Kong ${ }^{4}$. Our data spans from 2000 to 2017 and covers more than 1,200 large bank loans. The main findings indicate that family firms bear a higher cost of debt than nonfamily firms. The impact of family firms on

\footnotetext{
${ }^{4}$ We acknowledge that Hong Kong is a special administrative region rather than a country, but to preserve the continuity of the discussion we refer to it as a country (Carney and Child, 2013).
} 
the external financing cost is stronger in weaker institutional environments. The covenants help reduce the cost of debt while collateral is embedded in relatively riskier borrowers. We also find that small, highly leveraged borrowers pay higher loan spreads, while they are lower for firms with more tangible assets and lower probability of default risk.

Our paper contributes to family business and finance literature in different ways. First, we enrich family business literature by adding new lens of Asian family firms to Western skew in our current knowledge about these firms (Sharma and Chua, 2013). There has been a Western slant in the current literature on family enterprises, observed that $73 \%$ of family business research focuses on North American and European family enterprises (De Massis et al., 2012). Therefore, it is worth to have more understanding contextual nuances on the Eastern region to contribute to new knowledge about family firms around the world. This is important since family firms are not only the dominant but also a long-lasting organizational form in East Asia, the world's fastest - growing area (Claessens et al., 2000, Carney and Child, 2013, The Economist 2015), but the number of studies on 'Asian' family firms is still limited (De Massis et al., 2012, Sharma and Chua, 2013). In addition, the contextual environment in East Asia is unique, revealing of a convergence divergence paradox (Steier, 2009). It is globalizing, whilst still persisting unique institutional contexts. Therefore, studying family firms in East Asia contribute to the generality of knowledge about family business around the world.

Second, we contribute to family firms literature by studying the impact of family firms from the perspective of creditors in East Asia, given that Asian banks have been emerging lenders to the region in recent years beside traditional lenders from the United Kingdom, the United States, and the European Union (Nguyen et al., 2021). This is consistent with the efforts of East Asian 
countries to promote intra - regional financial integration starting with the Chiang Mai Initiative in 2000, the Asian Bond Markets Initiative in 2003, and culminating with the formation of the ASEAN Economic Community in 2015. The share of Asian banks rose from $16 \%$ in 2007 to $25 \%$ in 2018 (Nguyen et al., 2021).

Third, following the growing area of finance literature which suggests that culture plays an important role in financial outcomes, and motivated by Dinh and Calabrò (2019), we take into account the context of diverse religions in East Asia due to the significant divergent and influence of religion in this society (Cohen and Varnum, 2016), e.g. Islam (Indonesia, Malaysia), Buddhism (Thailand, Taiwan) and Christianity (Philippines). Indeed, religious orientation is a common informal institution considered in credits markets (Chui et al., 2016). Dinh and Calabrò (2019) argue that studying family business in Asia should look further into the religious elements since family firms have great incentives in pursuing socioemotional wealth (SEW) (Gómez-Mejía et al., 2007, Jiang et al., 2015) and religion may serve as a key driver of SEW. Extending the investigation of family firms with institutional contexts to countries with contrasting religions help provide better understandings of family firms (Soleimanof et al., 2018). To the best of our knowledge, this is the first cross-country study on family firms in East Asia that investigates the effect of family ownership on the cost of debt in the context of joint effect of formal and informal institutions.

The rest of the paper is structured as follows. Section 2 reviews the literature and proposes hypotheses. Section 3 presents data and methodology. Section 4 discusses the results. Section 5 provides the conclusion.

\section{LITERATURE REVIEW AND HYPOTHESES DEVELOPMENT}




\subsection{Low shareholders-creditors agency cost in family}

From the point of view of the resource based framework, the unique features of family firms align with the interest of creditors (Barney, 1991). When creditors perceive greater goal alignment with shareholders, the cost of debt could be lower (Anderson et al., 2003). Family owners as block holding and undiversified investors are less likely to pursue risky investments, reducing the risk of asset substitution for creditors (Carney, 2005). In addition, with objectives of transgenerational continuity, family reputation (Berrone et al., 2010) and social capital (Arregle et al., 2007), family firms should comply more with debt commitments. Furthermore, considering a family firm as a galaxy to pass to next generations, family members provide "patient capital" to firms (Bertrand and Schoar, 2006), reducing the risk of default for creditors. Managers in family firms usually affiliated with founding families are less likely to overinvest compared to managers with myopic view of nonfamily firms. In addition, family firms can enjoy a lower cost of debt which benefits

from the long - lasting closer relationship with creditors (Cucculelli et al., 2019). The impact of family involvement on business positively perceived by creditors could lead to a lower cost of debt for family firms.

\subsection{High shareholders - creditors agency cost in family}

In contrast with a positive view of family involvement, the cultural theory suggests a higher shareholder - creditor agency cost in family firms. This leads to a higher cost of debt for family firms. Family firms have a preference for private interest of control (Burkart et al., 2003) and capacity of expropriating minority shareholders and outside investors' wealth (Djankov et al., 2008, Jensen and Meckling, 1976, Claessens et al., 2002), particularly in countries with weak investor protection (Ellul et al., 2007, Djankov et al., 2008, Lins et al., 2013). Anderson et al. 
(2009) and Chen et al. (2014) find that family firms are more opaque than nonfamily firms. Family language provides an ideal environment for informational asymmetry. The greater the asymmetry of information, the more founding families can enhance their private wealth (Lang et al., 2004). More opaque information prevents outside investors from investing and increases the cost of external finance (Anderson et al., 2009, Ma et al., 2017, Myers and Majluf, 1984, Ferri and Murro, 2015). Furthermore, with private interest of control, family firms have more motivations for entrenchment and nepotism (Friedman et al., 2003, Pérez-González, 2006). Entrenchment theory suggests a negative relationship between firm performance and founding family ownership (Anderson et al., 2009, Claessens et al., 2002). In addition, the ownership concentration and dominant position of controlling families provide incentives and capacity to expropriate minority shareholders (Djankov et al., 2008, Jensen and Meckling, 1976), leading to poorer performance of family firms. These are negatively perceived by creditors, causing a higher cost of external finance for family firms (Ferri and Murro, 2015, Berger and Udell, 2006).

\subsection{Hypothesis development}

Firms exhibit different behaviors when operating in different social environments (Hilary and Hui, 2009), and family firms are no exceptions. In addition, family firms' behaviors are influenced by multiple institutional logics (Aparicio et al., 2017). We argue that family firms need to seek the fit between business activities and the different conflicting institutional logics such as the state or religions - based logics. On the one hand, with weak legal and institutional environments of East Asia, we argue that creditors bear higher risk when lending to family firms. The likelihood of minority shareholder wealth expropriation is high in a family firm due to weaker protection of investor right (Claessens et al., 2002, Villalonga and Amit, 2006). Creditors may face corporate 
credit risk caused by tunneling and manipulation by dominant shareholders in debt restructuring process (John et al., 2003, Gilson, 2005, Jiang et al., 2010). In addition, the opacity caused by the entrenchment effect from family management increases information asymmetry problems (Murro and Peruzzi, 2019, Ma et al., 2017); as a result, creditors face more asymmetical information when dealing with family firms (Anderson et al., 2009, Chen et al., 2008). These are negatively perceived by creditors (Aslan and Kumar, 2012), and may lead to increased cost of debt for family firms relative to nonfamily firms.

On the other hand, family firms are likely to produce less risk of opportunistic behaviors derived from family management due to religious influence. Theoretically, the religiosity is likely to positively associate with higher ethical standards and can play a key social role to constrain opportunistic behaviors of managers (Weaver and Agle, 2002, McGuire et al., 2012, Grullon et al., 2009). The higher ethical standards and strong self-discipline may mitigate the risk of engaging in fraudulent activities that jeoperdize the wealth of the debt holders (McGuire et al., 2012). In addition, many studies find a positive relationship between religiosity and risk aversion (Miller and Hoffmann, 1995, Dehejia et al., 2007). Risk aversion and long-term survivorship of family firms may reduce likelihood of investing in risky projects, which is aligned with creditors' interest. This reduces the agency costs between creditors and family firms.

However, while it is thoroughly agreed that the weak legal and institutional environments in East Asia motivate family to be more active to take advantages of the shortcomings of the institution frictions, the empirical evidence on reducing unethical behaves of firms due to religious concerns is not clear (Van Buren III et al., 2020, Vitell, 2009). Soleimanof et al. (2018) illustrate that family business assigns "different weights for different logics across different circumstances" 
(p.10). We argue that family firms' behaviors to fit the state - logic, formal institutions, are likely

to be convergent, meanwhile their behaviors to fit the religion - based seem being divergent. The explanation is that while laws are equally effective to all firms and organizations, ethical norms are more specific to the circumstance faced by their members (Sinclair, 1993) or depend on the deductive analogy (Mansour et al., 2015). Therefore, we argue that in the multiple or even conflicting logics, creditors with conservative perspectives are likely to skew the negative impacts of family involvement which are fostered in weak investor protection institutions. We hypothesize that:

Hypothesis 1: family firms suffer a higher cost of debt than nonfamily firms.

\section{METHODOLOGY}

In this section, we describe data collection, main variables, and model specification.

\subsection{Data collection}

First, we use ultimate beneficial ownership data from Carney and Child (2013). The data set provides the ultimate ownership of the largest 1386 publicly - traded firms (in terms of capital capitalization) in 9 East Asian countries including Japan, South Korea, Taiwan, HongKong, Singapore, Malaysia, Indonesia, the Philippines, and Thailand. ${ }^{5}$ We exclude all Japanese corporations to avoid outlier effects as Japanese firms are distinctive from the rest of the firms in East Asia. ${ }^{6}$ Then, we exclude financial institutions to follow the current literature (Lin et al., 2011,

\footnotetext{
${ }^{5}$ Carney and Child (2013) investigate the ultimate ownership of the largest 200 publicly-traded firms (in terms of market capitalization) from each of the countries' respective stock exchanges at the end of the calendar year 2008.

${ }^{6}$ Having widely dispersed ownership structures, the separation of ownership and management is more important in Japanese firms than in East Asian economies (Claessen et al., 2002). The largest shareholdings in Japanese firms are widely held by financial institutions, which is very different from many economies in the region. More importantly,
} 
Ma et al., 2017). The number of firms after excluded reduces to 919 firms. We obtain and calculate additional information about these firms from Thomson Reuters DataStream Advance on firm characteristics, such as firm size, profitability, tangibility, etc.

To track for the change in the type of ownership structure, we use M\&As data from Bloomberg for the period 2000 to 2017. Firm-year observations of those firms that are targets in M\&As transactions for which we cannot determine ultimate ownership after M\&A.

We next check the Dealscan database for available loan contract information in the 8 countries from 2000 to 2017. Dealscan provides deal-level data in each year, and various terms of the loans at origination, such as the loan spread, the maturity of the loan, the size of the loan, and the purpose of the loan. We use bank loans denominated in local currencies or either U.S. dollars, then convert the local currencies into U.S. dollars based on the exchange rate provided by Dealscan.

Finally, we merge data on loan contracts from Dealscan with ultimate ownership data of firms from Carney and Child (2013). We end up with 1,463 loan contracts during period from 2000 to 2017.

\subsection{Variables}

\section{Loan spread}

To gauge the cost of debt, we use the natural logarithm of loan spread ${ }^{7}$. Using natural logarithm help mitigate the effect of skewness in the data, following prior literature (Lin et al., 2011, Chava

financial institutions and their affiliated firms often cooperate to influence the governance of corporations, which is difficult to capture using formal ownership data.

${ }^{7}$ Detailed definitions for all the variables used in the paper are provided in Appendix 1. 
et al., 2009, Graham et al., 2008). Specifically, we use all-in-drawn spread measured in basis points over the London Interbank Offered Rate (LIBOR). This is LIBOR equivalent on a loan plus origination fees. Thus, it provides an all-inclusive measure of loan pricing at origination (Bharath et al., 2011).

\section{Family firm}

Family firm is our main explanatory variable of interest. Chua et al. (1999) define a family firm based on the involvement of family in ownership and governance and a vision of how the firm benefits the family, with these benefits potentially passing to the next generations:

"[A family firm is] governed and/or managed with the intention to shape and pursue the vision of the business held by a dominant coalition controlled by members of the same family or a small number of families in a manner that is potentially sustainable across generations of the family or families"

(Chua et al., 1999, p. 25)

Using Chua et al. (1999) definition of a family firm, O'Boyle et al. (2012) found that many scholars distinguish family firms from others based on the dimensions of ownership and governance, management, succession, and employment.

We follow one of the most common approaches to distinguish a family firm from others based on ownership (Claessens et al., 2000, Carney and Child, 2013, O'Boyle et al., 2012, Porta et al., 
1999, Faccio and Lang, 2000). A firm is defined as a family firm if family members represent the largest number of voting shareholders and hold at least 20 percent of ownership ${ }^{8}$.

\section{Control variables}

We control for a variety of factors that might affect loan pricing. These factors include borrower characteristics, loan characteristics, and country-level factors.

Firm-specific characteristics: We control for borrower size, leverage, profitability, asset tangibility, Q, and default risk. The current literature has shown that small firms face more informational asymmetry on the credit markets due to their opacity. As a result, smaller firms should suffer from higher loan spreads, other things equal (Ferri and Murro, 2015, Guiso and Minetti, 2010, Petersen and Rajan, 1994). Hence, we control for Firm_size, measured as the natural logarithm of total asset, following Petersen and Rajan (1994). Next, consistent with previous studies, we expect that profitable and low-leverage firms have lower loan spreads because they have lower probabilities of default (Lin et al., 2011, Murro and Peruzzi, 2019, Ferri and Murro, 2015, Chava et al., 2009). Thus, we include Profitability, measured by earnings before interest, tax, depreciation and amortization (EBITDA) over total assets and Leverage, measured as total debt divided by the sum of total debt and market value of equity. We control for Tangibility, measured by property, plant and equipment (PPE) over total assets. Tangible assets are often used as pledgeable assets as it has more value than intangible assets in financial distress (Almeida and Campello, 2007, Murro and Peruzzi, 2019), helping creditors to have high recovery values in default states. Consequently, creditors may offer lower spreads on loans for firms which have a high level of tangible assets (Lin et al., 2011, Kim et al., 2011, Zou and Adams, 2008). Following

\footnotetext{
${ }^{8}$ We use the cut-off value of 10 percent of ownership for robustness checks.
} 
Lin et al. (2011), we control for the market-to-book ratio or Q, measured as total assets minus book value of equity plus market value of equity divided by total assets, as a proxy for additional value that is left to creditors in default states (Graham et al., 2008). Finally, we proxy of default risk with the Altman Z-score (Altman, 2005) which is negatively associated with default risk 9 .

Loan-specific characteristics ${ }^{10}$ : Strahan (1999) finds that creditors often provide smaller, secured by collateral, covenants, and short maturity loans to borrowers that exhibit larger information asymmetry. We control for Loan_size, measured as natural logarithm of loan amount since banks may achieve the economies of scale. If so, the loan size should have negative relationship with the loan spreads. We control for loan maturity since the higher credit risk is associated with longer maturities. We also use dummy variables to control for the purpose of loans (working capital or general corporate purpose, refinancing, capital expenditures, acquisition, commercial paper backup, and others). We use dummy variables to control for covenant and collateral since these terms are often used in loan agreements to monitor borrowers and protect creditors (Strahan, 1999). Finally, we use prior relationship dummy variable to control for the relationship between firms and creditors as lending relationship helps reduce information asymmetry through information gathered over time (Berger and Udell, 1995, Bharath et al., 2011).

Country-level factors: Existing literature shows that institutional environment should have an impact on the shareholder - debtholder agency conflicts (Ellul et al., 2007, Claessens et al., 2000, Durnev and Kim, 2005). Qian and Strahan (2007) argue that stronger creditor protection provide greater bargaining power and ability to take control of firms and force repayment in case of

\footnotetext{
${ }^{9}$ Prior studies that use the Altman Z-score as a measure of default risk include Chava et al. (2009), Aslan and Kumar (2012), and D'Aurizio et al. (2015).

${ }^{10}$ These variables are frequently used by prior empirical works on bank loan pricing Chava et al. (2009), Aslan and Kurmar (2012), Graham et al. (2008) Hoffmann and Kleimeier (2019).
} 
default; in turn, creditors face less risk, and reduce the cost of debt. Among institutional environment factors, we control for creditor rights as legal creditor protection is the most important determinant of the quality of contracting environment between shareholder and creditor (Qian and Strahan, 2007, Bae and Goyal, 2009, Godlewski, 2020). We also controlled for GDP per capita which is a proxy of the economic development degree. Porta et al. (1998) show that laws and their enforcement vary across country as a function of GDP per capita.

In addition, prior research has shown that firms' behaviors are also influenced by religion based logics (Zhao and Lounsbury, 2016, Thornton et al., 2012). We take into account the diversity of religions in the region. Therefore, we control for different religions including Buddhism, Catholic and Islam by using dummy variables. Buddhism equals 1 if more than 50 percent of population of a country follows Buddhism, otherwise $0^{11}$. Catholic equals 1 if more than 50 percent of population of a country follows Catholic, otherwise 0 . Islam equals 1 if more than 50 percent of population of a country follows Islam, otherwise 0 .

\subsection{Model}

We use ordinary least square regressions to investigate the effect of family firms on the cost of debt. In model 1 (Eq1), we exclude non pricing loan characteristics - namely, loan size, maturity, loan purpose, secured, and covenant etc. - since they influence loan prices differently from other

\footnotetext{
${ }^{11}$ Except for Taiwan which has a proportion of population following Buddhism and Taoism at $35.3 \%$ and Taoist $33.2 \%$, respectively. Buddhism and Taoism share common value and beliefs with strong emphases on collectivism and familial interests (Lee et al. 1994). Chang (2012) find that Buddhism and Taoism religions have significant positive effects on strong family ties for all married individuals in Taiwan. Therefore, we consider people following Buddhism and Taoism in Taiwan as one group.
} 
control variables (Aslan and Kumar, 2012). In Model 2 (Eq2), we include important non pricing loan characteristics variables.

Loan_spread $=f($ Family_firm, Borrower characteristics, country - level factors $)$

Loan_spread $=f($ Family_firm, Borrower characteristics, Loan characteristics,

$$
\text { Country-level factors) }
$$

In Eq. (1) and Eq. (2), the dependent variable is the natural logarithm of the loan spread. The main explanatory variable of interest is family firm. Borrower variables are observed in the year before loan signing (Francis et al., 2012). We control for country - level variables in all models. We include annual year dummies and industry fixed effects in all regressions. Robust standard errors are clustered at the firm level (Petersen, 2009).

\section{RESULTS}

\subsection{Descriptive and univariate results}

Table 1 reports the number of firms which have bank loans versus firms which do not use bank loans for the full sample and for each country. Among 919 non - financial firms from ownership dataset of Carney and Child (2013), we report 28.9\% of firms use bank financing, indicating that firms may face financial constraints to access to bank financing ${ }^{12}$.

\section{[Insert Table 1 here]}

\footnotetext{
${ }^{12}$ However, it is worth noticing that Lozano and Yaman (2020) find that family firms seem to be financially less constrained in Europe.
} 
Table 2 reports univariate results for firm characteristics between two groups (firms using bank financing vs. firms not using bank financing) for all firms, and by firm status (family vs. nonfamily firms). Compared to firms which do not use bank financing, firms which use bank financing are larger and have more tangible assets with a statistically significant difference at the $1 \%$ level (Panel A). Larger firms have less asymmetric information and more tangible assets which are usually pledged as collateral (Almeida and Campello, 2007, Murro and Peruzzi, 2019). Hence, creditors face less risk when dealing with these firms. In addition, firms with access to bank loans have lower growth opportunity. Interestingly, there is no difference in Altman $\mathrm{Z}$ - score between the two groups. Firms which use bank financing have a negligibly lower average ROA than firms which do not use bank financing (10.76\% vs. $11.19 \%)$. The former group has a higher leverage ratio $(29.99 \%$ vs. $20.77 \%)$. We report similar results for the univariate tests for firms with bank loans versus firms that do not borrow from banks among family firms and among nonfamily firms only in Panels B and C, respectively. Among family firms, firms with bank borrowings are larger and have more tangibility. They also have a higher level of debt. The results are similar among nonfamily firms. We report that among nonfamily firms, firms that use bank financing have even better Altman Z - score.

\section{[Insert Table 2 here]}

Table 3 reports univariate results for firm characteristics between firms with bank loans versus firms without bank loans for each country. Results show that banks consistently prefer firms which are large and have more tangible assets across countries in our sample. Firms with bank loans have higher leverage ratio across countries. In some countries, firms which do not use bank financing have even better Altman $\mathrm{Z}$ - score than firms which use bank financing. 
[Insert Table 3 here]

We now turn to analyze the sample of all firms using bank financing, which is our main interest.

Table 4 presents descriptive statistics and univariate results for firm characteristics at the time bank loans are conducted for all borrowers, and by family versus nonfamily business borrowers. Panel A reports that the borrowers are large and profitable (averages at $\$ 5.3$ billion and $11 \%$ ). The mean of the leverage ratio is $32 \%$. The firms in the sample have substantial tangible assets (mean tangibility ratio of $46 \%$ ). The mean of market-to-book assets ratio is 1.3 . The average Altman Zscore is about 5.32, suggesting that borrowers have relatively low default risk. Family firms are significantly profitable, have more growth opportunities and have better Altman Z-score than nonfamily firms. For example, family firms have a higher EBITDA to total assets (13\% vs. 10\%), and higher market to book ratio (1.47 vs. 1.26). These differences between the two borrower groups are statistically significant at the $1 \%$ level. Panel B reports the differences in firm characteristics by family vs. nonfamily business borrowers in each country. The differences in firm characteristics between two groups vary from country to country.

\section{[Insert Table 4 here]}

In our sample, more than $78 \%$ of loans are for nonfamily firms (Fig. 1). Fig. 2 shows that family firms pay on average a spread of around $150 \mathrm{bps}$, while nonfamily firms pay around 100 bps. We remark that family firms pay a higher spread most of the time covered by the time span of the sample. Family firms pay a higher loan spread in most of the countries of the sample (except for Taiwan and South Korea). 
[Insert Figure 1 here]

[Insert Figure 2 here]

Fig. 3 shows non pricing loan terms by firm status. Compared to nonfamily firms, family firm loans are much less secured (14\% vs. $37 \%)$ and have much less covenants attached (11\% vs. $32 \%)$. The general corporate purpose is the most frequent loan purpose among family firms (37\%), while debt refinancing is the most frequent purpose among nonfamily firms (44\%). Furthermore, $41 \%$ of family firm loans are relationship loans while this percentage equals $62 \%$ for nonfamily firms.

[Insert Figure 3 here]

Table 5 shows mean, standard deviation and t-test for loan price. For all firms, the average loan spread is about 117 points with a large standard deviation (Panel A). Compared to nonfamily firms, the univariate results indicate that family firms pay a larger cost (156 pts vs. 106 pts) with a statistically significant difference at the $1 \%$ level. Panel B reports descriptive statistics and univariate results for key loan characteristics. The average loan size is about 199 million USD. The average loan maturity is about 57 months with substantial variation. About $57 \%$ of loans are relationship based. We notice that loans for family firms are larger (although the difference is not statistically significant) with shorter maturity (although the difference is economically small). $41 \%$ of loans among family firms' loans are relationship based, while for nonfamily firms it is about $61 \%$. We also remark that loans among family firms are less secured (15\% vs. $37 \%)$ and have less covenants (10\% vs. $31 \%)$. These differences are significant at the $1 \%$ level.

[Insert Table 5 here] 
Appendix 2 presents the correlation matrix of the variables used in the models. Regarding the correlations between the explanatory variables, there is no high correlation among them since there is no correlation coefficient larger than 0.6 . Therefore, it is unlikely that we have multicollinearity problems across these variables.

\subsection{Regression results}

Our univariate tests in Table 5 provide preliminary evidence that the cost of debt of family firms is significantly higher than for nonfamily firms. However, these univariate tests do not take into account potentially significant differences in loan and borrower characteristics between the family firms and nonfamily firms. We use multivariate tests to better understand how family firm status affects the cost of debt.

Table 6 reports the main results. Column 1 reports that the coefficient of Family firm is positive and statistically significant at 1 percent level, which indicates that family firms have a higher cost of debt than nonfamily firms. Comparing the results with Model 2, we find that controlling for other loan characteristics reduces only marginally the positive impact of family control on loan prices (Column 2).

We also find that the effects of firm size and Altman's Z-score on the loan price are negative and significant. These results are in line with previous studies (Lin et al., 2011, Chava et al., 2009, Hoffmann and Kleimeier, 2019). In addition, the effect of the tangibility on the loan spread is negative and significant at conventional levels, which is consistent with other studies (Lin et al., 2011, Francis et al., 2012). The market-to-book ratios are negatively related to loan prices and 
significantly after controlling for nonprice loan characteristics, implying that creditors value high growth firms (Francis et al., 2012).

Turning to the effect of loan characteristics on the loan spread in Model 2 (Column 2), we find that loans with covenants have lower loan spreads, suggesting that covenants help to reduce the potential conflicts of interest between firms and creditors and protect creditors against potential expropriation risks (Cremers et al., 2007). Secured loans have a higher loan price at the conventional level, which is consistent with the theoretical prediction that banks will require higher collateral when lending to relatively high-risk borrowers (Chava et al., 2009, Berger and Udell, 1990). We find that larger loan contracts have lower loan spreads, which is in line with Lin et al. (2011). The loan maturity has no effect on loan spreads. Our results indicate that borrowers do not gain benefits from lending relationship.

We also report the impact of country - level factors on the cost of debt in table 6 in both models. The coefficients of Creditor_right are negative and significant at the level of $1 \%$. The results indicate that stronger creditor right protection helps to reduce the cost of debt since creditors face less risk of opportunistic behaviors from lenders. We observe a divergent impact of religions on the cost of debt. While the coefficients for Buddhism are negative, the coefficients for Islam are positive. We can provide some explanations for these results following the hierarchical vs nonhierarchical religious organization. For instance Islam creates vertical bonds of obligations in society that do not encourage horizontal ties between people and may discourage trust (Putnam, 1993, Porta et al., 1996); while general trust is likely to be higher in non-hierarchical religions like Buddhism that promote a sense of individualized responsibility (Bjørnskov, 2007). In turn, higher 
trust reduce loan spreads when a country's formal institutions are weak (Álvarez-Botas and González, 2021).

\section{[Insert Table 6 here]}

\subsection{Robustness checks}

So far we have documented that family firms have a higher cost of debt compared to nonfamily firms. In this section we conduct a range of robustness checks of our results.

\section{Alternative proxy for family firm variable}

The prior empirical studies on family business have shown a variety of ways to define family firms (Prencipe et al., 2014, O'Boyle et al., 2012, Hernández-Linares et al., 2017). We acknowledge that results may be different corresponding to family firm classification. To examine whether our results are robust to the alternative proxy for a family firm, all firms in our sample are reclassified at the threshold of 10 percent ownership. A firm is classified as a family firm if the

ultimate largest voting shareholder that holds equal or more than 10 percent of ownership is a family. Then, we rerun all model specifications in our analysis. We report the results of these regressions in Table 7 . The results are strongly consistent. Our results so far firmly suggest that family firms have a higher cost of debt irrespective of the family firm classification.

\section{[Insert Table 7 here]}

\section{Endogeneity}


There may be a potential endogeneity problem in our study. Our study is safe from simultaneity since loan spreads are likely to be determined by competitive forces in the market and by the creditors; hence, it is not very likely that the loan spreads would affect corporate ownership and control (Lin et al., 2011). However, our results may be biased due to the presence of omitted variables that affect both loan spread and family firm status. To further address the endogeneity issue, we apply a two-stage instrumental variable estimation. We follow Wooldridge (2010) for models that have binary endogenous explanatory variable. In the first step, we estimate a binary response model by maximum likelihood; in the second step, we use the obtained fitted probability as an instrument. Wooldridge (2010) shows that this approach generates consistent coefficients, as well as correct standard errors.

We use the trust level in family as an instrumental variable for family firm. A good instrumental variable is expected to be correlated with family firm status, but unlikely to have direct impact on loan spread. Banfield (1967) finds that there is a potential trade-off between the trust among kinship networks and trust in society at large. He finds that "amoral familism" is one of the main reasons that affect the structure of a firm. Similarly, Fukuyama (1995) find that in a society where people are taught to trust only their family networks, they are also taught to distrust people outside the family. Sundaramurthy (2008) show that the existence of family firms are not purely based on economic optimization, but instead the outcome of trust. Therefore, we expect an association between the trust level in family and family firm status. Furthermore, Álvarez-Botas and González (2021) find that trust in general has no direct impact on the cost of bank loans. Therefore, we expect that trust level in family is less likely to have direct impact on loan spread. 
First, we run a probit model that includes the trust level in family and all explanatory variables used in our main model to obtain fitted probability for family firm. Second, we run IV estimation with instrumental variable which is fitted probability. Follow Alesina and Giuliano (2010), we measure the trust in the family based on the following question in the World Value Survey: "Could you tell me how much you trust your family?", where the answer could take the following values: "Trust them completely" (5), "Trust them a little" (4), "Neither trust or distrust them" (3), "Do not trust them very much" (2), and "Do not trust them at all" (1).

Table 8 reports results of probit model estimation, the first-stage and second-stage of IV 2SLS regressions in columns 1,2 and 3, respectively. Column 1 shows that the coefficient of Trustinfamily is negative and significant at the $1 \%$ level. Family firms in our sample are large publicly traded, while the high level of trust in family is considered as a competitive advantage for family businesses in the early stages (Sundaramurthy, 2008). Our results are supported by Steier (2001) who claims that "what was once a very resilient trust is replaced by an atmosphere of fragile trust," and unfortunately, this saga is a recurring theme in many family businesses.

Column 2 presents the results of first-stage regression of IV 2SLS estimation. We conduct two tests that provide support for our choice of instrument and report the results in the bottom of Column 2 in Table 8. We use the Durbin-Wu-Hausman (DWH) chi-squared test to test whether family firm is endogenous. The null hypothesis is that family firm is exogenous with respect to loan spread and the rejection of this hypothesis implies that family firm is indeed endogenous and validates the IV approach. To test whether our instrument is relevant, we calculate the CraggDonald statistic, which is 26.06 and is higher than the 11.04 critical value reported by Stock and Yogo (2005). This implies that our instrument for family firm is not weak. 
Column 2 of Table 8 show the regression results from the second stage. The coefficient of Family_firm is positive and statistically significant at the $1 \%$ level, suggesting that family firms suffer a higher cost of debt than nonfamily firms, reinforcing our earlier findings.

\section{[Insert Table 8 here]}

\section{Additional control variables}

In our sample, family firms bear a higher cost of debt than nonfamily firms in most countries, except for Taiwan and Korea. To test whether a higher cost of debt family firms pay is due to firm status (family firm vs. nonfamily firm) or primary derived from weak creditor right protection, we include an interaction term of Family_firm and Creditor_right in the model. If the higher cost of debt is primary due to weak creditor rights' protection, we expect an insignificant coefficient of Family_firm and a negative and significant coefficient of the interaction term. Column 1 of Table 9 shows that the coefficient of Family_firm is positive and significant at 1 percent level. The coefficient of Family_firm is even larger than without including the interaction term. The results indicate that family firms pay a higher cost of debt than nonfamily firms due to firm status. The coefficient of interaction term is negative and significant at 1 percent level, suggesting that the impact of family firms on the cost of debt is stronger in the weaker institutional environments.

Our results in Table 6 (Column 2) show that loans with covenants have lower loan spreads. This implies there may be a trade-off between covenants and loan spread. In our sample, only $10 \%$ of loans to family firms have covenants contrasting with $31 \%$ of loans to nonfamily firms. One concern is whether the higher debt financing costs of family firms substitutes for covenants requirement. To investigate the net effect of family firms on the cost of debt, we include the 
interaction term between family firm and a dummy equal to one if there is no covenants requirement. If not having covenants requirement is the driving force of the higher cost of debt family firms suffer, the coefficient of Family_firm would be insignificant and the coefficient of the interaction term would be significantly positive, implying that family firms pay a higher loan spread due the absence of covenants, not due to family firm status. Column 2 of Table 9 shows that the coefficient of the interaction term is negative and significant at $1 \%$, indicating that loans signed by family firms without covenants even have a lower loan spread than with covenants. The coefficient of Family_firm after including interaction term is larger. The results show that the presence of covenants is not a trade-off of a higher cost for the flexibility that family firms may intentionally choose. Hence, our results indicate that family firms face a higher cost of debt is robust.

Our results in Table 6 (Column 2) also indicate that secured loans have higher loan spreads. In our sample, family firms have less secured loans ${ }^{13}$ than nonfamily firm (15\% versus $37 \%$ respectively). To investigate whether the positive relationship between family firms and the cost of debt may be driven by the presence of collateral, we include an interaction term between Family_firm and Secured variables. If collateral is the driving force of the higher cost of debt for family firms, the interaction term would be significantly positive. However, Column 3 shows that the interaction term is insignificant, indicating that the impact of family ownership on loan spread

\footnotetext{
${ }^{13}$ In investigating the impact of family firm status on the loan spread, we focus on the dynamic loan characteristics that creditors and borrowers can bargain, such as covenants and secured, rather than loan purpose since loan purpose is the primal factor on which borrowers stick and that creditors are unable to ask for change. We still, however, check whether the positive relationship between family firms and the cost of debt may be driven by the loan purpose since in our sample, family firms borrow most for the general corporate purpose (37\%), while nonfamily firms borrow most for debt refinancing purpose (44\%). We include an interaction term between family firm and corporate purpose dummy variables in the model. Our results show that the loan general corporate purpose has no impact on the relationship between family firms and loan spread.
} 
is not moderated by collateral. The impact of family ownership status on the cost of debt is confirmed.

Finally, since our timespan covers the financial crisis period, one can wonder if the effect of family firms on the cost of debt might be overstated. Bernanke et al. (1996) find that adverse shocks in financial markets may amplify the intrinsic cost of agency conflicts in the relationship between borrowers and creditors, affecting some types of borrowers disproportionately. Prior literature shows that family firms would move out of equilibrium in a way that magnifies either the benefits or the costs of family control in the financial crisis (D'Aurizio et al., 2015, Lins et al., 2013). Based on previous studies, we determine financial crisis period that is from 2008 to 2009 (Lins et al., 2013, Aldamen et al., 2020). To achieve the reliability of analysis, we add an interaction term between family firm dummy and crisis dummy. Column 4 reports that the coefficient of the interaction term is insignificant, suggesting that including external financial shocks does not overstate the effect of family firm on the cost of debt.

[Insert Table 9 here]

\section{CONCLUSION}

Given the limited number of studies on family business in East Asia, we investigate the impact of family firms on the cost of debt in East Asia during the period from 2000 to 2017. Acknowledging that family firms are influenced by multiple factors, we consider the impact of family firms on the cost of debt financing in the context of formal and informal institutions. We find consistent evidence that family firms pay a significant higher cost of debt (loan spreads). Family firms pay even higher cost of debt in weak institutional environments. We document that 
stronger creditor protection legal helps reduce the cost of debt, while religions have divergent impact on the cost of debt. We further find that loan spreads are higher for firms with small size and high leverage. On the other hand, we report that loan spreads are lower for firms with more tangible assets and low default risk. Furthermore, covenants help reduce the cost of debt while collateral is embedded in relatively riskier borrowers. Overall, our results highlight the impact of family firms on the cost of debt. Our results survive several robustness checks related to endogeneity and heteroskedasticity issues, and family firm classification.

We believe that our study enriches family business literature by adding "Asian" family firms to Western slant in the current literature on family enterprises, contributing to the knowledge about family firms around the world.

This study has some limitations that need to be acknowledged. East Asia is an ideal context for our study; however, the number of firms which can be chased the ultimate ownership use bank financing is not large, implicating that firms may turn to the alternative sources of financing. There remains a need to collect more data to study the impact of family firms on the alternative debt financing which would contribute to the generalizability of our findings. Moreover, family businesses are not a homogenous group, and therefore, future research should identify different types of family businesses. Finally, empirical examination of the relationship between the cost of equity and family ownership in East Asia offers an exciting avenue for further research. 
Appendix 1: Definition of variables and sources

\begin{tabular}{lll}
\hline Variables & Definition & Source \\
\hline Dependent variable & $\begin{array}{l}\text { Natural logarithm of the loan spread. Loan spread is the all-in-drawn spread, Dealscan } \\
\text { defined as the amount the borrower pays in basis points over LIBOR or LIBOR } \\
\text { equivalent for the drawn portion of the loan facility }\end{array}$ \\
\hline Borrower characteristics & $\begin{array}{l}\text { Equals to 1 if the largest shareholder who holds at least 20\% of ownership is a Carney (2013) } \\
\text { family or individual, 0 otherwise. }\end{array}$ \\
\hline Family_firm & Natural logarithm of total assets in thousands of \$US. & DataStream \\
\hline Firm_size & $\begin{array}{l}\text { Ratio of total debt (long-term plus short-term debt) to market value of a firm. } \\
\text { Market value of a firm is defined by market value of equity plus book value of } \\
\text { total debt. }\end{array}$ \\
\hline Leverage & $\begin{array}{l}\text { Ratio of earnings before interest, tax, depreciation and amortization (EBITDA) } \\
\text { over total assets }\end{array}$ & DataStream \\
\hline Profitability & Ratio of net property, plant, and equipment (PPE) over to total assets & DataStream \\
\hline Tangibility & $\begin{array}{l}\text { Qis defined by total assets minus book value of equity plus market value of equity } \\
\text { divided by total assets. }\end{array}$ & DataStream
\end{tabular}

\begin{tabular}{|c|c|c|}
\hline Altman_Zscore & $\begin{array}{l}\text { We apply the Z-score model developed by Altman }(2005) \text { for the emerging } \\
\text { market as follows: } \\
\text { Altman_Zscore }=6.56 * \mathrm{X} 1+3.26 * \mathrm{X} 2+6.72 * \mathrm{X} 3+1.05 * \mathrm{X} 4+3.25 \\
\text { Where: } \\
\mathrm{X} 1=\text { Working Capital/Total Assets; } \\
\mathrm{X} 2=\text { Retained Earnings/Total Assets; } \\
\mathrm{X} 3=\text { Earnings before Interest and Taxes/Total Assets; } \\
\mathrm{X} 4=\text { book value of equity/total liabilities. }\end{array}$ & $\begin{array}{l}\text { Author's } \\
\text { calculation }\end{array}$ \\
\hline \multicolumn{3}{|c|}{ Loan characteristics } \\
\hline Loan_size & Natural logarithm of a loan facility amount, measured in millions of US dollars & Dealscan \\
\hline Loan_maturity & $\begin{array}{l}\text { Natural logarithm of the numbers of months from the intercept day to expired day } \\
\text { of a loan facility }\end{array}$ & Dealscan \\
\hline Loan_purp. & $\begin{array}{l}\text { Dummy variables for loan purposes, including corporate purpose/working capital } \\
\text { purpose, refinancing purpose, acquisition purpose, capital expenditure purpose, } \\
\text { backup line purpose, and others }\end{array}$ & Dealscan \\
\hline Secured & Equals to 1 if a loan is secured, 0 otherwise & Dealscan \\
\hline Covenant & Equals to 1 if a loan contract contains financial covenants, 0 otherwise & Dealscan \\
\hline Prior_rel & $\begin{array}{l}\text { Equals to } 1 \text { if a firm has the past loan signed with the same creditor within } 5 \text { years, } \\
\text { and } 0 \text { otherwise }\end{array}$ & \\
\hline \multicolumn{3}{|c|}{ Country level variable } \\
\hline Creditor rights & $\begin{array}{l}\text { An index aggregating creditor rights, following Porta et al. (1998). A score of one } \\
\text { is assigned when each of the following rights of secured lenders is defined in laws } \\
\text { and regulations: First, there are restrictions, such as creditor consent or minimum } \\
\text { dividends, for a debtor to file for reorganization. Second, secured creditors are able } \\
\text { to seize their collateral after the reorganization petition is approved, i.e. there is no } \\
\text { "automatic stay" or "asset freeze." Third, secured creditors are paid first out of the } \\
\text { proceeds of liquidating a bankrupt firm, as opposed to other creditors such as } \\
\text { government or workers. Finally, if management does not retain administration of }\end{array}$ & $\begin{array}{l}\text { Djankov et al. } \\
(2007)\end{array}$ \\
\hline
\end{tabular}




\begin{tabular}{|c|c|c|}
\hline & $\begin{array}{l}\text { its property pending the resolution of the reorganization. The index ranges from } \\
0 \text { (weak creditor rights) to } 4 \text { (strong creditor rights) }{ }^{14} \text {. }\end{array}$ & \\
\hline GDPpercapita & Gross domestic product per capita & World bank \\
\hline Buddhism & $\begin{array}{l}\text { Equals to } 1 \text { if more than } 50 \text { percent of population of a country follows Buddhism; } \\
\text { otherwise } 0^{15} \text {. }\end{array}$ & $\begin{array}{l}\text { Central } \\
\text { Intelligence } \\
\text { Agency }\end{array}$ \\
\hline Catholic & $\begin{array}{l}\text { Equals to } 1 \text { if more than } 50 \text { percent of population of a country follows Catholicism; } \\
\text { otherwise } 0 .\end{array}$ & $\begin{array}{l}\text { Central } \\
\text { Intelligence } \\
\text { Agency }\end{array}$ \\
\hline Islam & $\begin{array}{l}\text { Equals to } 1 \text { if more than } 50 \text { percent of population of a country follows Islam; } \\
\text { otherwise } 0 .\end{array}$ & $\begin{array}{l}\text { Central } \\
\text { Intelligence } \\
\text { Agency }\end{array}$ \\
\hline Trustinfamily & $\begin{array}{l}\text { Trust level in family is the average score of all individual respondents in each } \\
\text { country for the question: } \\
\text { "Could you tell me how much you trust your family?" } \\
\text { 1. "Trust them completely" }-5 \text { scores; } \\
\text { 2. "Trust them a little" }-4 \text { scores; } \\
\text { 3. "Neither trust or distrust them" }-3 \text { scores; } \\
\text { 4. "Do not trust them very much" }-2 \text { scores; } \\
\text { 5. "Do not trust them at all" }-1 \text { score. }\end{array}$ & WVS \\
\hline
\end{tabular}

\footnotetext{
${ }^{14}$ The La Porta et al. (1996) measure of creditor rights is available for a single cross section of countries (year 1995). The Djankov et al. (2007) and the La Porta et al. (1996) measures are highly correlated. However, Djankov et al. (2007) improves on the La Porta et al.(1996) measure by providing a time series of this variable.

${ }^{15}$ Except for Taiwan which has proportion of population follow Buddhism and Taoism are 35.3\% and Taoist 33.2\%, respectively. Buddhism and Taoism share common value and beliefs with strong emphases on collectivism and familial interests (Lee et al. 1994). Chang (2012) find that Buddhism and Taoism religions have significantly positive related. Therefore, we consider people follow Buddhism and Taoism in Taiwan as one group.
} 


\begin{tabular}{|c|c|c|c|c|c|c|c|c|c|c|}
\hline & $\begin{array}{l}\text { Loan_spr } \\
\text { ead }\end{array}$ & Loan_size & $\begin{array}{l}\text { Loan_maturi } \\
\text { ty }\end{array}$ & Secured & Covernant & Prior_rel & Firm_size & Leverage & Profitability & $Q$ \\
\hline Loan_spread & 1.000 & & & & & & & & & \\
\hline Loan_size & $-0.086^{* *}$ & 1.000 & & & & & & & & \\
\hline Loan_maturity & $-0.087 * *$ & 0.015 & 1.000 & & & & & & & \\
\hline Secured & -0.001 & 0.050 & $0.171 * * *$ & 1.000 & & & & & & \\
\hline Covernant & $-0.090 * *$ & 0.017 & 0.029 & $0.115^{* * *}$ & 1.000 & & & & & \\
\hline Prior_rel & $-0.116 * * *$ & 0.019 & 0.045 & $0.116^{* * *}$ & $0.226 * * *$ & 1.000 & & & & \\
\hline Firm_size & $-0.083^{* *}$ & $0.450 * * *$ & $-0.076^{* *}$ & $-0.108 * * *$ & -0.052 & $0.081 * *$ & 1.000 & & & \\
\hline Leverage & $0.083^{* *}$ & $-0.125^{* * *}$ & $0.097 * * *$ & 0.027 & $-0.099 * * *$ & $0.161 * * *$ & $0.112 * * *$ & 1.000 & & \\
\hline Profitability & 0.004 & $0.119 * * *$ & -0.024 & $-0.086^{* *}$ & -0.023 & $-0.066^{*}$ & $-0.084 * *$ & $-0.368 * * *$ & 1.000 & \\
\hline$Q$ & 0.006 & $0.059 *$ & $-0.061 *$ & $-0.084 * *$ & -0.025 & $-0.126^{* * *}$ & $-0.173 * * *$ & $-0.503 * * *$ & $0.464 * * *$ & 1.000 \\
\hline Tangibility & $-0.087 * *$ & 0.046 & $0.188 * * *$ & 0.052 & $-0.165 * * *$ & 0.022 & $0.151 * * *$ & $0.375 * * *$ & $0.085^{* *}$ & $-0.109 * * *$ \\
\hline Altman_Zscore & -0.032 & -0.023 & 0.027 & $-0.092 * *$ & $0.065^{*}$ & $-0.081 * *$ & $-0.254 * * *$ & $-0.533 * * *$ & $0.502 * * *$ & $0.396 * * *$ \\
\hline Creditor_right & -0.010 & $0.107 * * *$ & $-0.092 * * *$ & $-0.208 * * *$ & $-0.242 * * *$ & $-0.239 * * *$ & $0.237 * * *$ & 0.017 & -0.035 & $-0.081 * *$ \\
\hline GDPpercapita & $-0.163 * * *$ & $0.103 * * *$ & $-0.072 *$ & -0.025 & $0.114 * * *$ & $0.075^{* *}$ & $0.187 * * *$ & -0.027 & $-0.193 * * *$ & $-0.185^{* * *}$ \\
\hline Buddhism & $-0.352 * * *$ & $-0.075^{* *}$ & $0.075 * *$ & $0.300 * * *$ & $0.359 * * *$ & $0.310^{* * * *}$ & $-0.231 * * *$ & -0.054 & $-0.176 * * *$ & $-0.065^{*}$ \\
\hline Catholic & $0.209 * * *$ & -0.001 & 0.006 & $-0.109 * * *$ & $-0.074 * *$ & -0.016 & 0.009 & 0.031 & $0.068^{*}$ & 0.018 \\
\hline Islam & $0.287 * * *$ & 0.018 & -0.031 & $-0.055^{*}$ & $-0.111 * * *$ & $-0.191 * * *$ & $-0.164 * * *$ & $-0.096 * * *$ & $0.255^{* * *}$ & $0.308 * * *$ \\
\hline
\end{tabular}


Appendix 2 (Cont.): Correlation matrix

\begin{tabular}{|c|c|c|c|c|c|c|c|}
\hline & Tangibility & Altman_Zscore & Creditor_right & GDPpercapita & Buddhism & Catholic & Islam \\
\hline Tangibility & 1.000 & & & & & & \\
\hline EM_score & $-0.359 * * *$ & 1.000 & & & & & \\
\hline Creditor_right & 0.039 & -0.040 & 1.000 & & & & \\
\hline GDPpercapita & $-0.184 * * *$ & -0.025 & $0.584 * * *$ & 1.000 & & & \\
\hline Buddhism & $-0.168 * * *$ & 0.002 & $-0.473 * * *$ & $0.209 * * *$ & 1.000 & & \\
\hline Catholic & $0.055^{*}$ & 0.027 & $-0.472 * * *$ & $-0.451 * * *$ & $-0.315^{* * *}$ & 1.000 & \\
\hline Islam & $0.060 *$ & $0.164 * * *$ & -0.020 & $-0.480 * * *$ & $-0.371 * * *$ & $-0.067 *$ & 1.000 \\
\hline
\end{tabular}




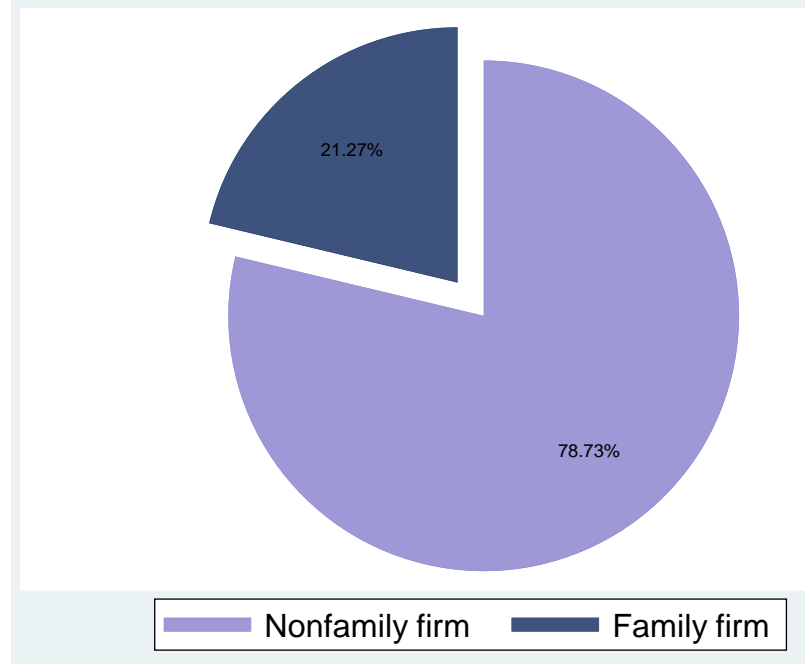

Fig. 1. Number of loans by firm status 


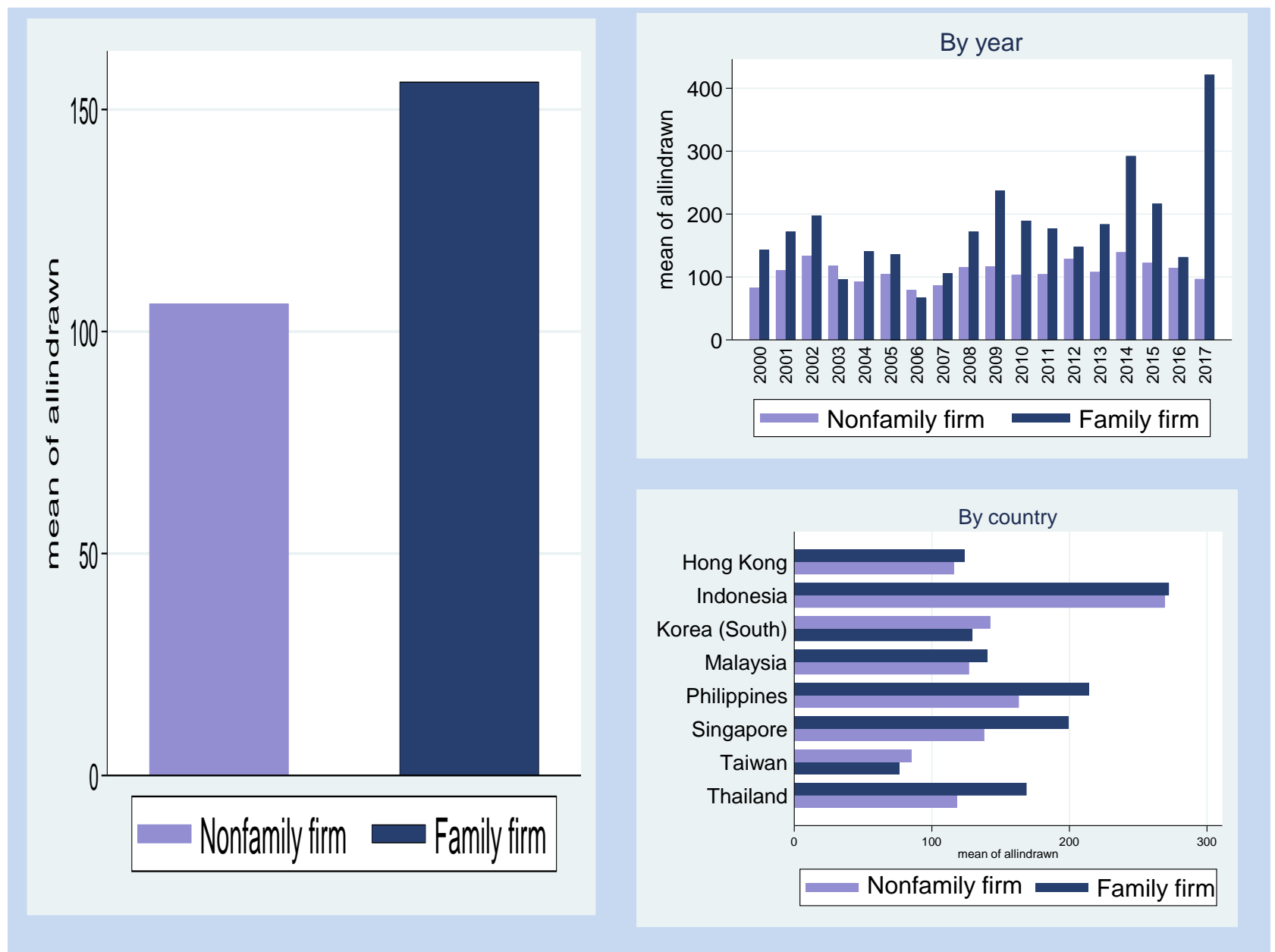

Fig. 2. Loan spread of family firm vs. nonfamily firm 


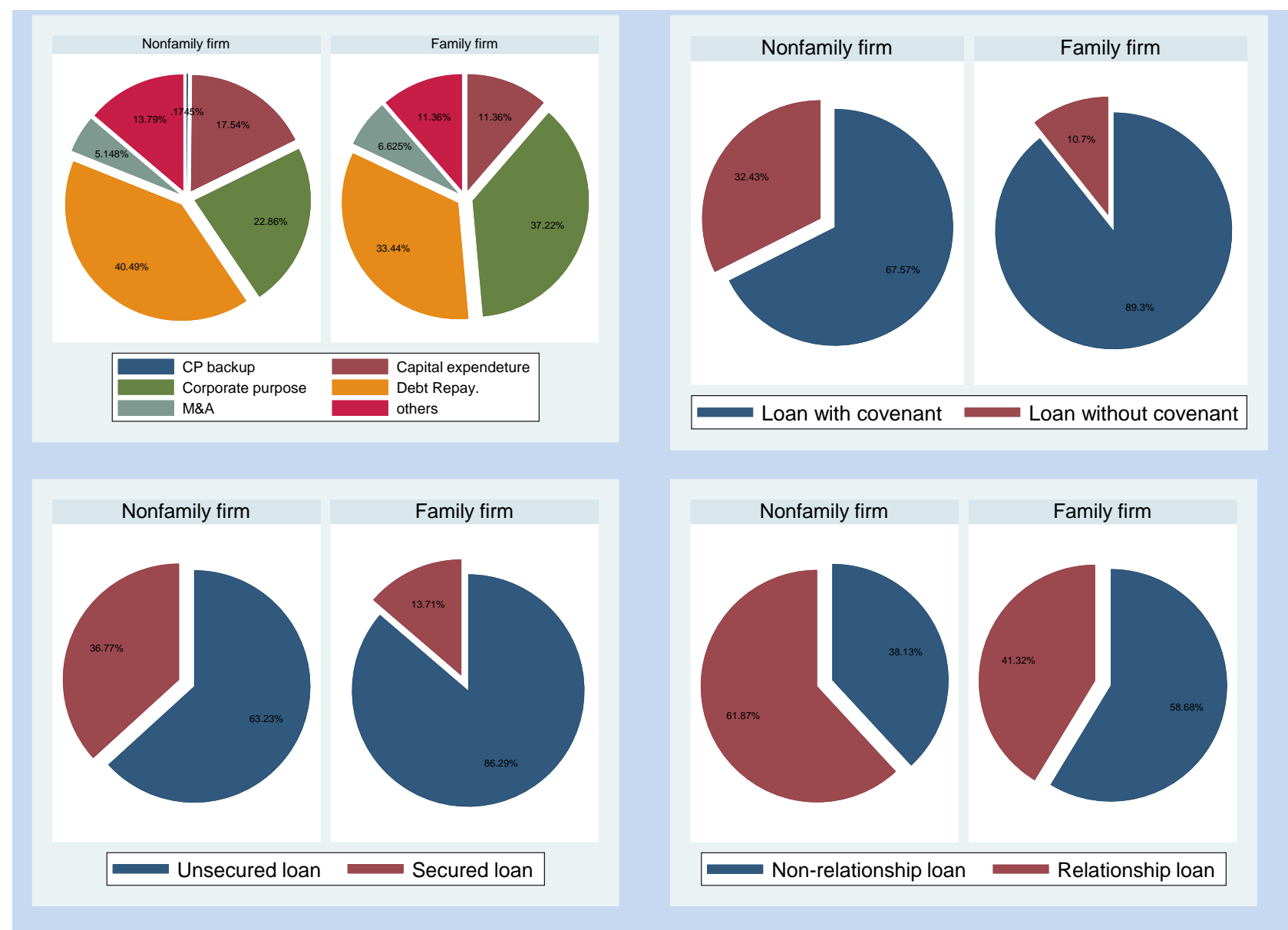

Fig. 3. Loan charactersitics by firm status 
Table 1: Firms which use bank financing by country

\begin{tabular}{llll}
\hline & Total firms & $\begin{array}{l}\text { Firms use } \\
\text { bank financing }\end{array}$ & $\begin{array}{l}\text { Firms do not use } \\
\text { bank financing }\end{array}$ \\
\hline & 919 & 266 & 653 \\
$(100 \%)$ & $(28.9 \%)$ & $(72.1 \%)$ \\
\hline HKG & 106 & 23 & 83 \\
IDN & 100 & 26 & 74 \\
KOR & 146 & 55 & 91 \\
MYS & 125 & 29 & 96 \\
PHL & 73 & 16 & 57 \\
SGP & 106 & 25 & 81 \\
THA & 118 & 27 & 91 \\
TWN & 145 & 65 & 80 \\
\hline
\end{tabular}


Table 2:

This table reports univariate results of firm characteristics between firms which use bank financing vs. firms which do not use bank financing for all firms, and by firm status (family firms vs. nonfamily firms)

\begin{tabular}{|c|c|c|c|}
\hline & $\begin{array}{l}\text { Firms use } \\
\text { bank financing }\end{array}$ & $\begin{array}{l}\text { Firms do not use } \\
\text { bank financing }\end{array}$ & T-test \\
\hline \multicolumn{4}{|c|}{ Panel A: All firms } \\
\hline Firm_size & 14.51 & 12.79 & $(-74.89)^{* * *}$ \\
\hline Leverage & 29.98 & 20.75 & $(-37.88)^{* * *}$ \\
\hline Profitability & 10.75 & 11.22 & $(3.88)^{* * *}$ \\
\hline$Q$ & 1.36 & 1.51 & $(11.66)^{* * *}$ \\
\hline Tangibility & 42.07 & 36.02 & $(-19.48)^{* * *}$ \\
\hline Altman_Zscore & 5.39 & 6.19 & -1.8 \\
\hline \multicolumn{4}{|c|}{ Panel B: Family firms } \\
\hline Firm_size & 14.5 & 12.59 & $(-45.58)^{* * * *}$ \\
\hline Leverage & 32.06 & 22.93 & $(-19.41)^{* * * *}$ \\
\hline Profitability & 10.99 & 10.26 & $(-3.33) * * *$ \\
\hline$Q$ & 1.39 & 1.4 & -0.46 \\
\hline Tangibility & 44.49 & 38.22 & $(-10.76)^{* * *}$ \\
\hline Altman_Zscore & 4.93 & 4.9 & $(-0.03)$ \\
\hline \multicolumn{4}{|c|}{ Panel C: Nonfamily firms } \\
\hline Firm_size & 14.51 & 12.96 & $(-50.80)^{* * *}$ \\
\hline Leverage & 29.01 & 18.87 & $(-32.94)^{* * * *}$ \\
\hline Profitability & 10.54 & 12.19 & $(10.44)^{* * *}$ \\
\hline$Q$ & 1.34 & 1.6 & $(16.57)^{* * *}$ \\
\hline Tangibility & 41.15 & 34.32 & $(-16.92)^{* * * *}$ \\
\hline Altman_Zscore & 5.56 & 7.07 & $(3.45)^{* * *}$ \\
\hline
\end{tabular}


Table 3:

This table reports univariate results of firm characteristic between two groups: firms use bank financing vs. firms that do use bank financing by country

\begin{tabular}{|c|c|c|c|c|c|c|c|c|c|c|c|c|}
\hline & $\begin{array}{l}\text { Firms use } \\
\text { bank } \\
\text { financing }\end{array}$ & $\begin{array}{l}\text { Firms do } \\
\text { not use } \\
\text { bank } \\
\text { financing }\end{array}$ & T-test & $\begin{array}{l}\text { Firms } \\
\text { use bank } \\
\text { financing }\end{array}$ & $\begin{array}{l}\text { Firms do } \\
\text { not use } \\
\text { bank } \\
\text { financing }\end{array}$ & T-test & $\begin{array}{l}\text { Firms } \\
\text { use bank } \\
\text { financing }\end{array}$ & $\begin{array}{l}\text { Firms do } \\
\text { not use } \\
\text { bank } \\
\text { financing }\end{array}$ & T-test & $\begin{array}{l}\text { Firms } \\
\text { use bank } \\
\text { financing }\end{array}$ & $\begin{array}{l}\text { Firms do } \\
\text { not use } \\
\text { bank } \\
\text { financing }\end{array}$ & T-test \\
\hline & \multicolumn{3}{|l|}{ HKG } & \multicolumn{3}{|l|}{ PHL } & \multicolumn{3}{|l|}{ KOR } & \multicolumn{3}{|l|}{ THA } \\
\hline Firm_size & 15.05 & 13.06 & $(-22.14)^{* * *}$ & 14.23 & 11.64 & $(-24.51)^{* * *}$ & 15.63 & 13.87 & $(-35.68)^{* * *}$ & 13.99 & 12.41 & $(-17.09)^{* * *}$ \\
\hline Leverage & 27.65 & 20.3 & $(-9.39)^{* * *}$ & 36.06 & 21.96 & $(-11.97)^{* * *}$ & 36.85 & 22.18 & $(-25.37)^{* * *}$ & 28.55 & 23.66 & $(-4.52)^{* * *}$ \\
\hline Profitability & 9.37 & 6.07 & $(-8.90) * * *$ & 12.52 & 9.24 & $(-6.24)^{* * *}$ & 9.87 & 11.18 & $(5.52)^{* * *}$ & 15.29 & 13.27 & $(-3.93)^{* * *}$ \\
\hline$Q$ & 1.39 & 1.16 & $(-7.59) * * *$ & 1.58 & 1.46 & $(-1.80)$ & 1.08 & 1.51 & $(15.34)^{* * *}$ & 1.7 & 1.56 & $(-3.07) * *$ \\
\hline Tangibility & 37.41 & 28.99 & $(-8.42)^{* * *}$ & 43.94 & 38.5 & $(-3.69) * * *$ & 44.63 & 35.07 & $(-16.04)^{* * *}$ & 44.5 & 40.53 & $(-3.10)^{* *}$ \\
\hline \multirow[t]{2}{*}{ Altman_Zscore } & 6.32 & 9.99 & $(4.11)^{* * *}$ & 3.77 & -0.9 & $(-0.40)$ & 4.48 & 6.51 & $(14.59)^{* * *}$ & 6.08 & 8.75 & -1.88 \\
\hline & \multicolumn{3}{|l|}{ IDN } & \multicolumn{3}{|l|}{ SGP } & \multicolumn{3}{|l|}{ MYS } & \multicolumn{3}{|l|}{ TWN } \\
\hline Firm_size & 13.75 & 12.35 & $(-23.40)^{* * *}$ & 13.93 & 12.44 & $(-21.98)^{* * *}$ & 14.1 & 12.98 & $(-16.57)^{* * *}$ & 14.26 & 13.32 & $(-21.93)^{* * *}$ \\
\hline Leverage & 30.24 & 24.19 & $(-6.40)^{* * *}$ & 23.12 & 19.31 & $(-5.64)^{* * *}$ & 31.27 & 19.59 & $(-14.05)^{* * *}$ & 27.55 & 11.36 & $(-31.19)^{* * *}$ \\
\hline Profitability & 14.12 & 13.77 & $(-0.73)$ & 10.65 & 9.1 & $(-3.89) * * *$ & 9.47 & 12.26 & $(6.24) * * *$ & 10.07 & 15.02 & $(22.41)^{* * *}$ \\
\hline$Q$ & 1.75 & 1.64 & $(-2.51)^{*}$ & 1.58 & 1.45 & $(-3.04)^{* *}$ & 1.27 & 1.48 & $(3.91)^{* * *}$ & 1.3 & 1.96 & $(27.69)^{* * *}$ \\
\hline Tangibility & 48.1 & 40.2 & $(-7.83) * * *$ & 39.02 & 33.44 & $(-5.02) * * *$ & 47.8 & 39.6 & $(-6.38)^{* * *}$ & 39.55 & 27.22 & $(-16.97)^{* * *}$ \\
\hline Altman_Zscore & 4.55 & -0.39 & $(-0.60)$ & 5.73 & 1.69 & $(-0.64)$ & 6.11 & 9.01 & $(6.15)^{* * *}$ & 5.96 & 9.07 & $(25.94) * * *$ \\
\hline
\end{tabular}


Table 4:

This table reports descriptive and univariate results for firm characteristics by family firms vs. nonfamily firms for full sample and for each country

Panel A: Full sample

\begin{tabular}{|c|c|c|c|c|c|c|c|c|c|c|c|c|}
\hline & \multicolumn{3}{|c|}{ Full sample } & \multicolumn{2}{|c|}{ Family firms } & \multicolumn{4}{|c|}{ Nonfamily firms } & & & \\
\hline & Mean & $S D$ & $\operatorname{Max}$ & Min & Mean & $S D$ & Mean & $S D$ & $T$-test & & & \\
\hline Firm_size & 14.77 & 1.26 & 18.47 & 7.66 & 14.89 & 1.44 & 14.73 & 1.21 & $(-1.88)$ & & & \\
\hline Leverage & 32.41 & 17.74 & 83.23 & 0 & 31.77 & 17.71 & 32.58 & 17.75 & -0.68 & & & \\
\hline Profitability & 11.06 & 8.37 & 68.14 & -38.62 & 13.22 & 7.87 & 10.5 & 8.4 & $(-4.88) * * *$ & & & \\
\hline$Q$ & 1.3 & 0.78 & 11.98 & 0.43 & 1.47 & 0.95 & 1.26 & 0.73 & $(-4.02)^{* * *}$ & & & \\
\hline Tangibility & 0.46 & 0.22 & 0.98 & 0.01 & 0.47 & 0.19 & 0.45 & 0.22 & $(-1.22)$ & & & \\
\hline Altman_Zscore & 5.32 & 2.21 & 17.41 & -8.14 & 5.69 & 2.41 & 5.22 & 2.15 & $(-3.18)^{* *}$ & & & \\
\hline Total_assets & $5.34 \mathrm{E}+09$ & $8.39 E+09$ & $1.05 \mathrm{E}+10$ & $2.12 \mathrm{E}+06$ & $7.56 \mathrm{E}+09$ & $1.37 \mathrm{E}+09$ & $4.76 \mathrm{E}+09$ & $6.18 \mathrm{E}+09$ & $(-5.09) * * *$ & & & \\
\hline \multicolumn{13}{|c|}{ Panel B: By country } \\
\hline & $\begin{array}{l}\text { Family } \\
\text { firm }\end{array}$ & $\begin{array}{l}\text { Nonfamily } \\
\text { firm }\end{array}$ & T-test & $\begin{array}{l}\text { Family } \\
\text { firm }\end{array}$ & $\begin{array}{l}\text { Nonfamily } \\
\text { firm }\end{array}$ & T-test & $\begin{array}{l}\text { Family } \\
\text { firm }\end{array}$ & $\begin{array}{l}\text { Nonfamily } \\
\text { firm }\end{array}$ & T-test & $\begin{array}{l}\text { Family } \\
\text { firm }\end{array}$ & $\begin{array}{l}\text { Nonfamily } \\
\text { firm }\end{array}$ & T-test \\
\hline & HKG & & & KOR & & & PHL & & & THA & & \\
\hline Firm_size & 15.11 & 15 & $(-0.78)$ & 15.98 & 15.4 & $(-8.67) * * *$ & 13.95 & 15.21 & $(5.34) * * *$ & 13.45 & 14.26 & $(8.68) * * *$ \\
\hline Leverage & 23.83 & 30.13 & $(4.87)^{* * *}$ & 34.88 & 38.09 & $(3.89)^{* * *}$ & 36.32 & 34.38 & $(-1.08)$ & 26.99 & 30.19 & $(2.19)^{*}$ \\
\hline Profitability & 11.32 & 8.12 & $(-7.58) * * *$ & 11.13 & 9.02 & $(-7.06) * * *$ & 11.68 & 16.36 & $(4.05)^{* * *}$ & 14.13 & 15.12 & -1.34 \\
\hline$Q$ & 1.49 & 1.33 & $(-2.62)^{* *}$ & 1.09 & 1.06 & $(-2.08)^{*}$ & 1.62 & 1.39 & $(-2.19)^{*}$ & 1.79 & 1.58 & $(-2.55)^{*}$ \\
\hline Tangibility & 35.57 & 38.62 & -1.77 & 40.85 & 47.7 & $(6.59)^{* * *}$ & 41.87 & 53.48 & $(4.51)^{* * *}$ & 54.39 & 39.11 & $(-5.40)^{* * *}$ \\
\hline \multirow[t]{2}{*}{ Altman_Zscore } & 8.35 & 5.05 & $(-11.62)^{* * *}$ & 4.59 & 4.41 & $(-2.43)^{*}$ & 3.14 & 5.23 & $(2.51)^{*}$ & 5.84 & 6.07 & -1.17 \\
\hline & IDN & & & MYS & & & SGP & & & TWN & & \\
\hline Firm_size & 13.53 & 13.9 & $(5.87)^{* * *}$ & 14.08 & 14.18 & -0.68 & 12.82 & 14.48 & $(13.00)^{* * *}$ & 14.32 & 14.26 & $(-0.56)$ \\
\hline Leverage & 33.74 & 26.3 & $(-6.15)^{* * *}$ & 30.76 & 30.97 & -0.15 & 30.14 & 19.46 & $(-8.84)^{* * *}$ & 31.07 & 27.37 & $(-2.50)^{*}$ \\
\hline Profitability & 10.76 & 17.35 & $(9.60)^{* * *}$ & 10.8 & 8.74 & $(-4.84) * * *$ & 9.82 & 10.7 & -1.11 & 7.98 & 10.17 & $(4.10)^{* * *}$ \\
\hline$Q$ & 1.61 & 1.83 & $(3.30)^{* *}$ & 1.37 & 1.21 & $(-4.17) * * *$ & 1.29 & 1.7 & $(6.40)^{* * *}$ & 1.35 & 1.3 & $(-1.36)$ \\
\hline Tangibility & 50.52 & 44.91 & $(-3.10)^{* *}$ & 47.24 & 48.69 & -0.6 & 49.37 & 34.17 & $(-7.45)^{* * *}$ & 45.32 & 39.24 & $(-3.13)^{* *}$ \\
\hline Altman_Zscore & 2.51 & 6.1 & $(5.89) * * *$ & 7.06 & 5.38 & $(-7.32) * * *$ & 6.25 & 5.28 & $(-5.09)^{* * *}$ & 5.37 & 5.99 & $(3.44)^{* * *}$ \\
\hline
\end{tabular}


Table 5: Descriptive statistics for loan characteristics by firm status

\begin{tabular}{lllllllllc}
\hline & \multicolumn{3}{c}{ Full sample } & \multicolumn{2}{c}{ Family firms } & \multicolumn{2}{c}{ Nonfamily firms } \\
\cline { 2 - 10 } & Mean & SD & Max & Min & Mean & SD & Mean & SD & T-test \\
\hline Panel A: Loan price & & & & & & & \\
\hline All_in_drawn & 117.20 & 88.30 & 700.00 & 2.00 & 156.99 & 114.83 & 106.20 & 75.88 & $(-9.33)^{* * *}$ \\
Loan_spread & 4.54 & 0.66 & 6.55 & 0.69 & 4.79 & 0.77 & 4.47 & 0.60 & $(-7.63)^{* * *}$ \\
\hline Panel B: Loan characteristics & & & & & & & \\
\hline Facility amount & $1.99 \mathrm{e}+08$ & $3.86 \mathrm{e}+08$ & $6.00 \mathrm{e}+09$ & 0.00 & $1.74 \mathrm{e}+08$ & $4.01 \mathrm{e}+08$ & $2.06 \mathrm{e}+08$ & $3.82 \mathrm{e}+08$ & -1.31 \\
Maturity(months) & 57.60 & 29.44 & 240.00 & 1.00 & 54.31 & 30.77 & 58.50 & 29.01 & $(2.23)^{*}$ \\
Loan_size & 18.43 & 1.14 & 22.52 & 13.30 & 18.34 & 1.08 & 18.45 & 1.16 & -1.51 \\
Loan_maturity & 3.92 & 0.55 & 5.48 & 0.00 & 3.84 & 0.60 & 3.95 & 0.54 & $(3.17)^{* *}$ \\
Secured & 0.32 & 0.47 & 1.00 & 0.00 & 0.15 & 0.35 & 0.37 & 0.48 & $(7.66)^{* * *}$ \\
Covernant & 0.27 & 0.44 & 1.00 & 0.00 & 0.10 & 0.30 & 0.31 & 0.46 & $(7.71)^{* * *}$ \\
Prior_rel & 0.57 & 0.49 & 1.00 & 0.00 & 0.41 & 0.49 & 0.62 & 0.49 & $(6.64)^{* * *}$ \\
\hline
\end{tabular}


Table 6:

This table reports results of ordinary least square (OLS) regressions. The dependent variable is natural logarithm of all in drawn spread. A family firm is defined as a firm in which the largest shareholder who holds at least $20 \%$ of ownership is a family or individual. Variables are described in Appendix 1. Dummy variables for loan purpose, industry fixed effect and year fixed effect are included in the models but not reported. Numbers in the parentheses are standard errors clustered at the firm level. ***, **, * denote statistical significance at the $1 \%, 5 \%$, and $10 \%$ levels, respectively.

\begin{tabular}{|c|c|c|}
\hline & $\begin{array}{c}\text { Model } 1 \\
(1)\end{array}$ & $\begin{array}{c}\text { Model } 2 \\
(2)\end{array}$ \\
\hline Family_firm & $\begin{array}{c}0.125^{* * *} \\
(0.042)\end{array}$ & $\begin{array}{c}0.109 * * \\
(0.042)\end{array}$ \\
\hline Firm_size & $\begin{array}{c}-0.117 * * * \\
(0.014)\end{array}$ & $\begin{array}{c}-0.093 * * * \\
(0.016)\end{array}$ \\
\hline Leverage & $\begin{array}{c}0.004 * * * \\
(0.001)\end{array}$ & $\begin{array}{c}0.003 * * * \\
(0.001)\end{array}$ \\
\hline Profitability & $\begin{array}{c}0.004 \\
(0.003)\end{array}$ & $\begin{array}{c}0.006 * * \\
(0.003)\end{array}$ \\
\hline$Q$ & $\begin{array}{l}-0.036 \\
(0.024)\end{array}$ & $\begin{array}{c}-0.050 * * \\
(0.023)\end{array}$ \\
\hline Tangibility & $\begin{array}{c}-0.279 * * * \\
(0.102)\end{array}$ & $\begin{array}{c}-0.260 * * \\
(0.105)\end{array}$ \\
\hline Altman_Zscore & $\begin{array}{c}-0.019 * \\
(0.010)\end{array}$ & $\begin{array}{c}-0.020 * * \\
(0.010)\end{array}$ \\
\hline Loan_size & & $\begin{array}{c}-0.045 * * * \\
(0.016)\end{array}$ \\
\hline Loan_maturity & & $\begin{array}{c}0.024 \\
(0.030)\end{array}$ \\
\hline Covenant & & $\begin{array}{c}-0.224 * * * \\
(0.038)\end{array}$ \\
\hline Secured & & $\begin{array}{c}0.090 * * * \\
(0.033)\end{array}$ \\
\hline Prior_rel & & $\begin{array}{l}-0.050 \\
(0.036)\end{array}$ \\
\hline Creditor_right & $\begin{array}{c}-0.537 * * * \\
(0.107)\end{array}$ & $\begin{array}{c}-0.514 * * * \\
(0.109)\end{array}$ \\
\hline GDPpercapita & $\begin{array}{c}0.000 * * * \\
(0.000)\end{array}$ & $\begin{array}{c}0.000 * * * \\
(0.000)\end{array}$ \\
\hline Buddhism & $\begin{array}{c}-1.034 * * * \\
(0.120)\end{array}$ & $\begin{array}{c}-0.976^{* * * *} \\
(0.124)\end{array}$ \\
\hline Catholic & $\begin{array}{l}-0.279 \\
(0.212)\end{array}$ & $\begin{array}{l}-0.220 \\
(0.221)\end{array}$ \\
\hline Islam & $\begin{array}{c}0.399 * * * \\
(0.117)\end{array}$ & $\begin{array}{c}0.358 * * * \\
(0.120)\end{array}$ \\
\hline Intercept & $7.863^{* * *}$ & $9.017 * * *$ \\
\hline
\end{tabular}


$(0.350)$

Loan purpose control

Industry fixed effect

Year fixed effect

Obs.

Adj.R2
No

Yes

Yes

1278

0.430
(0.508)

Yes

Yes

Yes

1252

0.460 
Table 7:

This table reports results of ordinary least square (OLS) regressions. The dependent variable is natural logarithm of all in drawn spread. A family firm is defined as a firm in which the largest shareholder who holds at least $10 \%$ of ownership is a family or individual. Variables are described in Appendix 1. Dummy variables for loan purpose, industry fixed effect and year fixed effect are included in the models but not reported. Numbers in the parentheses are standard errors clustered at the firm level. ***, **, * denote statistical significance at the $1 \%, 5 \%$, and $10 \%$ levels, respectively.

\begin{tabular}{|c|c|c|}
\hline & $\begin{array}{c}\text { Model } 1 \\
\text { (1) }\end{array}$ & $\begin{array}{c}\text { Model } 2 \\
(2)\end{array}$ \\
\hline Family_firm & $\begin{array}{c}0.131 * * * \\
(0.037)\end{array}$ & $\begin{array}{c}0.123 * * * \\
(0.037)\end{array}$ \\
\hline Firm_size & $\begin{array}{c}-0.145 * * * \\
(0.015)\end{array}$ & $\begin{array}{c}-0.126 * * * \\
(0.018)\end{array}$ \\
\hline Leverage & $\begin{array}{c}0.002 * * \\
(0.001)\end{array}$ & $\begin{array}{l}0.002 * \\
(0.001)\end{array}$ \\
\hline Profitability & $\begin{array}{c}0.004 \\
(0.003)\end{array}$ & $\begin{array}{l}0.005^{*} \\
(0.003)\end{array}$ \\
\hline$Q$ & $\begin{array}{c}-0.052 * * \\
(0.024)\end{array}$ & $\begin{array}{c}-0.071 * * * \\
(0.024)\end{array}$ \\
\hline Tangibility & $\begin{array}{l}-0.119 \\
(0.104)\end{array}$ & $\begin{array}{l}-0.067 \\
(0.108)\end{array}$ \\
\hline Altman_Zscore & $\begin{array}{l}-0.012 \\
(0.009)\end{array}$ & $\begin{array}{l}-0.010 \\
(0.010)\end{array}$ \\
\hline Loan_size & & $\begin{array}{c}-0.030 * \\
(0.017)\end{array}$ \\
\hline Loan_maturity & & $\begin{array}{c}0.029 \\
(0.032)\end{array}$ \\
\hline Covenant & & $\begin{array}{c}-0.231 * * * \\
(0.038)\end{array}$ \\
\hline Secured & & $\begin{array}{c}0.084 * * \\
(0.033)\end{array}$ \\
\hline Prior_rel & & $\begin{array}{l}-0.062 \\
(0.039)\end{array}$ \\
\hline Creditor_right & $\begin{array}{c}-0.524 * * * \\
(0.112)\end{array}$ & $\begin{array}{c}-0.479 * * * \\
(0.112)\end{array}$ \\
\hline GDPpercapita & $\begin{array}{c}0.000 * * * \\
(0.000)\end{array}$ & $\begin{array}{c}0.000 * * \\
(0.000)\end{array}$ \\
\hline Buddhism & $\begin{array}{c}-1.069 * * * \\
(0.117)\end{array}$ & $\begin{array}{c}-0.977 * * * \\
(0.116)\end{array}$ \\
\hline Catholic & $\begin{array}{c}-0.553 * * * \\
(0.185)\end{array}$ & $\begin{array}{c}-0.454 * * \\
(0.189)\end{array}$ \\
\hline Islam & $\begin{array}{l}-0.156 \\
(0.147)\end{array}$ & $\begin{array}{c}-0.316^{* *} \\
(0.146)\end{array}$ \\
\hline Intercept & $8.044 * * *$ & $8.644 * * *$ \\
\hline
\end{tabular}


(0.380)

Loan purpose control

Industry fixed effect

Year fixed effect

Obs.

Adj.R2
No

Yes

Yes

1220

0.420
(0.406)

Yes

Yes

Yes

1196

0.450 
Table 8:

This table reports results of probit model in Column 1, and instrumental variable two-stage least square (IV 2SLS) in columns 2 and 3. We investigate the impact of family firms on the cost of debt for a sample of over 1,200 syndicated loans from eight East Asian countries during the period from 2000 to 2017. The cut-off level of ownership is $20 \%$. A family firm is defined as a firm in which the largest shareholder who holds at least $20 \%$ of ownership is a family or individual. The dependent variable is natural logarithm of all in drawn spread. Fitted_Pro_FF is the fitted probability of a family firm from probit model. Dummy variables for loan purpose, industry fixed effect and year fixed effect are included in the models but not reported. Numbers in the parentheses are standard errors clustered at the firm level. $* * *, * *, *$ denote statistical significance at the $1 \%, 5 \%$, and $10 \%$ levels, respectively.

\begin{tabular}{|c|c|c|c|}
\hline & Probit Model & First - stage IV & Second - stage IV \\
\hline & $\begin{array}{c}\text { Dependent variable: } \\
\text { Family_firm }\end{array}$ & $\begin{array}{c}\text { Dependent variable: } \\
\text { Family_firm }\end{array}$ & $\begin{array}{c}\text { Dependent variable: } \\
\text { Loan_spread }\end{array}$ \\
\hline & $(1)$ & (2) & (3) \\
\hline \multirow[t]{2}{*}{ Family_firm } & & & $0.764 * * *$ \\
\hline & & & $(0.287)$ \\
\hline \multirow[t]{2}{*}{ Trustinfamily } & $-17.808 * * *$ & & \\
\hline & $(6.189)$ & & \\
\hline \multirow[t]{2}{*}{ Fitted_Pro_FF } & & $0.910 * * *$ & \\
\hline & & 0.178 & \\
\hline \multirow[t]{2}{*}{ Firm_size } & $0.080 *$ & 0.002 & $-0.103 * * *$ \\
\hline & $(0.048)$ & $(0.012)$ & $(0.017)$ \\
\hline \multirow[t]{2}{*}{ Leverage } & 0.001 & 0.000 & $0.003 * *$ \\
\hline & $(0.004)$ & $(0.001)$ & $(0.001)$ \\
\hline \multirow[t]{2}{*}{ Profitability } & -0.008 & -0.000 & $0.006 * *$ \\
\hline & $(0.008)$ & $(0.002)$ & $(0.003)$ \\
\hline \multirow[t]{2}{*}{$Q$} & 0.044 & 0.002 & $-0.063 * *$ \\
\hline & $(0.070)$ & $(0.018)$ & $(0.027)$ \\
\hline \multirow[t]{2}{*}{ Tangibility } & $-0.533^{*}$ & -0.015 & -0.161 \\
\hline & $(0.283)$ & $(-0.65)$ & $(0.119)$ \\
\hline \multirow[t]{2}{*}{ Altman_Zscore } & 0.054 & 0.002 & $-0.025 * *$ \\
\hline & $(0.033)$ & $(0.005)$ & $(0.010)$ \\
\hline \multirow[t]{2}{*}{ Loan_size } & -0.035 & .001 & $-0.038 * *$ \\
\hline & $(0.049)$ & $(0.010)$ & $(0.017)$ \\
\hline \multirow[t]{2}{*}{ Loan_maturity } & 0.000 & -0.000 & 0.025 \\
\hline & $(0.082)$ & $(-0.021)$ & $(0.033)$ \\
\hline \multirow[t]{2}{*}{ Secured } & $-0.492 * * *$ & -0.001 & $-0.174 * * *$ \\
\hline & $(0.122)$ & $(-0.022)$ & $(0.043)$ \\
\hline \multirow[t]{2}{*}{ Covenant } & $-0.447 * * *$ & -0.009 & $0.137 * * *$ \\
\hline & $(0.148)$ & $(0.030)$ & $(0.038)$ \\
\hline \multirow[t]{2}{*}{ Prior_rel } & 0.005 & 0.0001 & -0.044 \\
\hline & $(0.107)$ & $(0.026)$ & $(0.040)$ \\
\hline \multirow[t]{2}{*}{ Creditor_right } & 0.059 & -0.019 & $-0.516^{* * *}$ \\
\hline & $(0.248)$ & $(0.074)$ & $(0.112)$ \\
\hline GDPpercapita & $-0.000 * * *$ & 0.000 & $0.000 * * *$ \\
\hline
\end{tabular}




\begin{tabular}{lccc} 
& $(0.000)$ & $(0.000)$ & $(0.000)$ \\
Buddhism & $-0.546^{*}$ & -0.036 & $-0.877^{* * *}$ \\
& $(0.281)$ & $(0.086)$ & $(0.140)$ \\
Catholic & 0.435 & -0.032 & -0.294 \\
& $(0.477)$ & $(0.150)$ & $(0.237)$ \\
Islam & -0.067 & 0.009 & 0.216 \\
& $(0.380)$ & $(0.092)$ & $(0.135)$ \\
Intercept & $14.197^{* * *}$ & 0.021 & $7.837^{* * *}$ \\
& $(5.444)$ & $(0.284)$ & $(0.437)$ \\
\hline Loan purpose & & & Yes \\
control & Yes & Yes & Yes \\
Industry fixed effect & Yes & Yes & Yes \\
Year fixed effect & Yes & 1250 & 1250 \\
\hline Obs. & 1250 & 0.240 & 0.340 \\
Adj.R2 & & & \\
Durbin-Wu- & & 0.014 & \\
Hausman & & 26.06 & \\
(DWH)(p_value $)$ & & & \\
Cragg-Donald & & & \\
\hline
\end{tabular}


Table 9:

This table reports results of ordinary least square (OLS) regressions. The dependent variable is natural logarithm of all in drawn spread. A family firm is defined as a firm in which the largest shareholder who holds at least $20 \%$ of ownership is a family or individual. Variables are described in Appendix 1. Dummy variables for loan purpose, industry fixed effect and year fixed effect are included in the models but not reported. Numbers in the parentheses are standard errors clustered at the firm level. ***,**,* denote statistical significance at the $1 \%, 5 \%$, and $10 \%$ levels, respectively.

\begin{tabular}{|c|c|c|c|c|}
\hline & (1) & (2) & (3) & (4) \\
\hline Family_Own & $\begin{array}{c}0.478 * * * \\
(0.137)\end{array}$ & $\begin{array}{c}0.387 * * * \\
(0.094)\end{array}$ & $\begin{array}{c}0.100 * * \\
(0.046)\end{array}$ & $\begin{array}{c}0.101 * * \\
(0.046)\end{array}$ \\
\hline FF_Creditorright & $\begin{array}{c}-0.149 * * * \\
(0.055)\end{array}$ & & & \\
\hline$F F \_n o c o v e n a n t$ & & $\begin{array}{c}-0.321 * * * \\
(0.101)\end{array}$ & & \\
\hline FF_secured & & & $\begin{array}{c}0.059 \\
(0.109)\end{array}$ & \\
\hline FF_crisis & & & & $\begin{array}{c}0.046 \\
(0.120)\end{array}$ \\
\hline Firm_size & $\begin{array}{c}-0.093 * * * \\
(0.016)\end{array}$ & $\begin{array}{c}-0.094 * * * \\
(0.016)\end{array}$ & $\begin{array}{c}-0.093 * * * \\
(0.016)\end{array}$ & $\begin{array}{c}-0.093 * * * \\
(0.016)\end{array}$ \\
\hline Leverage & $\begin{array}{c}0.003 * * * \\
(0.001)\end{array}$ & $\begin{array}{c}0.003 * * * \\
(0.001)\end{array}$ & $\begin{array}{c}0.003 * * * \\
(0.001)\end{array}$ & $\begin{array}{c}0.003 * * * \\
(0.001)\end{array}$ \\
\hline Profitability & $\begin{array}{c}0.006 * * \\
(0.003)\end{array}$ & $\begin{array}{c}0.006 * * \\
(0.003)\end{array}$ & $\begin{array}{c}0.006 * * \\
(0.003)\end{array}$ & $\begin{array}{c}0.006 * * \\
(0.003)\end{array}$ \\
\hline$Q$ & $\begin{array}{c}-0.053 * * \\
(0.023)\end{array}$ & $\begin{array}{c}-0.055^{* *} \\
(0.023)\end{array}$ & $\begin{array}{c}-0.050 * * \\
(0.023)\end{array}$ & $\begin{array}{c}-0.050 * * \\
(0.023)\end{array}$ \\
\hline Tangibility & $\begin{array}{c}-0.248^{* *} \\
(0.105)\end{array}$ & $\begin{array}{c}-0.286^{* * *} \\
(0.105)\end{array}$ & $\begin{array}{c}-0.256^{* *} \\
(0.106)\end{array}$ & $\begin{array}{c}-0.260 * * \\
(0.105)\end{array}$ \\
\hline Altman_Zscore & $\begin{array}{l}-0.020 * \\
(0.010)\end{array}$ & $\begin{array}{c}-0.021 * * \\
(0.010)\end{array}$ & $\begin{array}{c}-0.020 * * \\
(0.010)\end{array}$ & $\begin{array}{c}-0.020 * * \\
(0.010)\end{array}$ \\
\hline Loan_size & $\begin{array}{c}-0.041 * * \\
(0.016)\end{array}$ & $\begin{array}{c}-0.044 * * * \\
(0.016)\end{array}$ & $\begin{array}{c}-0.045^{* * *} \\
(0.016)\end{array}$ & $\begin{array}{c}-0.045 * * * \\
(0.016)\end{array}$ \\
\hline Loan_maturity & $\begin{array}{c}0.026 \\
(0.030)\end{array}$ & $\begin{array}{c}0.023 \\
(0.030)\end{array}$ & $\begin{array}{c}0.025 \\
(0.030)\end{array}$ & $\begin{array}{c}0.024 \\
(0.030)\end{array}$ \\
\hline Covenant & $\begin{array}{c}-0.223 * * * \\
(0.037)\end{array}$ & & $\begin{array}{c}-0.223 * * * \\
(0.038)\end{array}$ & $\begin{array}{c}-0.223 * * * \\
(0.038)\end{array}$ \\
\hline Nocovenant & & $\begin{array}{c}0.266^{* * * *} \\
(0.039)\end{array}$ & & \\
\hline Secured & $\begin{array}{c}0.097 * * * \\
(0.033)\end{array}$ & $\begin{array}{c}0.095 * * * \\
(0.033)\end{array}$ & $\begin{array}{c}0.084 * * \\
(0.034)\end{array}$ & $\begin{array}{c}0.089 * * * \\
(0.033)\end{array}$ \\
\hline Prior_rel & $\begin{array}{l}-0.046 \\
(0.036)\end{array}$ & $\begin{array}{l}-0.049 \\
(0.036)\end{array}$ & $\begin{array}{l}-0.049 \\
(0.036)\end{array}$ & $\begin{array}{l}-0.050 \\
(0.036)\end{array}$ \\
\hline Creditor_right & $\begin{array}{c}-0.474 * * * \\
(0.112)\end{array}$ & $\begin{array}{c}-0.507 * * * \\
(0.108)\end{array}$ & $\begin{array}{c}-0.517 * * * \\
(0.110)\end{array}$ & $\begin{array}{c}-0.513 * * * \\
(0.110)\end{array}$ \\
\hline
\end{tabular}




\begin{tabular}{lcccc} 
GDPpercapita & $0.000^{* * *}$ & $0.000^{* * *}$ & $0.000^{* * *}$ & $0.000^{* * * *}$ \\
Buddhism & 0.000 & 0.000 & 0.000 & 0.000 \\
& $-0.980^{* * *}$ & $-0.966^{* * *}$ & $-0.981^{* * *}$ & $-0.974 * * *$ \\
Catholic & $(0.124)$ & $(0.123)$ & $(0.125)$ & $(0.124)$ \\
& -0.293 & -0.238 & -0.224 & -0.215 \\
Islam & $(0.219)$ & $(0.218)$ & $(0.221)$ & $(0.221)$ \\
& $0.322^{* * *}$ & $0.357^{* * *}$ & $0.353^{* * *}$ & $0.360^{* * *}$ \\
Crisis & $(0.119)$ & $(0.120)$ & $(0.120)$ & $(0.120)$ \\
& & & & 0.118 \\
Intercept & & & & $(0.097)$ \\
& $8.819^{* * *}$ & $8.324 * * *$ & $9.026 * * *$ & $9.019 * * *$ \\
Obs. & $(0.515)$ & $(0.521)$ & $(0.508)$ & $(0.508)$ \\
Adj.R2 & 1252 & 1252 & 1252 & 1252 \\
\hline
\end{tabular}




\section{References}

ALDAMEN, H., DUNCAN, K., KELLY, S. \& MCNAMARA, R. 2020. Corporate governance and family firm performance during the Global Financial Crisis. Accounting \& Finance, 60, 1673-1701.

ALESINA, A. \& GIULIANO, P. 2010. The power of the family. Journal of Economic Growth, 15, 93-125.

ALMEIDA, H. \& CAMPELLO, M. 2007. Financial constraints, asset tangibility, and corporate investment. Review of Financial Studies, 20, 1429-1460.

ALTMAN, E. I. 2005. An emerging market credit scoring system for corporate bonds. Emerging Markets Review, 6, 311-323.

ÁLVAREZ-BOTAS, C. \& GONZÁLEZ, V. M. 2021. Does trust matter for the cost of bank loans? Journal of Corporate Finance, 66, 101791.

ANDERSON, R. C., DURU, A. \& REEB, D. M. 2009. Founders, heirs, and corporate opacity in the United States. Journal of Financial Economics, 92, 205-222.

ANDERSON, R. C., DURU, A. \& REEB, D. M. 2012. Investment policy in family controlled firms. Journal of Banking and Finance, 36, 1744-1758.

ANDERSON, R. C., MANSI, S. A. \& REEB, D. M. 2003. Founding family ownership and the agency cost of debt. Journal of Financial Economics, 68, 263-285.

APARICIO, G., BASCO, R., ITURRALDE, T. \& MASEDA, A. 2017. An exploratory study of firm goals in the context of family firms: An institutional logics perspective. Journal of Family Business Strategy, 8, 157-169.

ARREGLE, J. L., HITT, M. A., SIRMON, D. G. \& VERY, P. 2007. The development of organizational social capital: Attributes of family firms. Journal of Management Studies, 44, 73-95.

ASLAN, H. \& KUMAR, P. 2012. Strategic ownership structure and the cost of debt. Review of Financial Studies, 25, 2257-2299.

BAE, K. H. \& GOYAL, V. K. 2009. Creditor rights, enforcement, and bank loans. Journal of Finance, 64, 823-860.

BANFIELD, E. C. 1967. The moral basis of a backward society. Free Press.

BARNEY, J. 1991. Firm resources and sustained competitive advantage. Journal of Management, 17, 99-120.

BERGER, A. N. \& UDELL, G. F. 1990. Collateral, loan quality and bank risk. Journal of Monetary Economics, 25, 21-42.

BERGER, A. N. \& UDELL, G. F. 1995. Relationship lending and lines of credit in small firm finance. Journal of Business, 68, 351-381.

BERGER, A. N. \& UDELL, G. F. 2006. A more complete conceptual framework for SME finance. Journal of Banking and Finance, 30, 2945-2966.

BERNANKE, B., GERTLER, M. \& GILCHRIST, S. 1996. The financial accelerator and the flight to quality. Review of Economics and Statistics, 78, 1-15.

BERRONE, P., CRUZ, C., GOMEZ-MEJIA, L. R. \& LARRAZA-KINTANA, M. 2010. Socioemotional wealth and corporate responses to institutional pressures: Do family-controlled firms pollute less? Administrative Science Quarterly, 55, 82-113.

BERTRAND, M. \& SCHOAR, A. 2006. The role of family in family firms. Journal of Economic Perspectives, 20, 73-96.

BHARATH, S. T., DAHIYA, S., SAUNDERS, A. \& SRINIVASAN, A. 2011. Lending relationships and loan contract terms. Review of Financial Studies, 24, 1141-1203.

BJØRNSKOV, C. 2007. Determinants of generalized trust: A cross-country comparison. Public Choice, 130, 1-21.

BOUBAKRI, N. \& GHOUMA, H. 2010. Control/ownership structure, creditor rights protection, and the cost of debt financing: International evidence. Journal of Banking and Finance, 34, 2481-2499.

BRIANO-TURRENT, G.D.C., LI M. \& PENG H. 2020. The impact of family-CEOs and their demographic characteristics on dividend payouts: Evidence from Latin America. Research in International Business and Finance, 51, 101086.

BURKART, M., PANUNZI, F. \& SHLEIFER, A. 2003. Family firms. Journal of Finance, 58, 2167-2202.

CARNEY, M. 2005. Corporate governance and competitive advantage in family-controlled firms. Entrepreneurship Theory and Practice, 29, 249-265.

CARNEY, M. \& GEDAJLOVIC, E. 2002. The co-evolution of institutional environments and organizational strategies: The rise of family business groups in the ASEAN region. Organization Studies, 23, 1-29.

CARNEY, R. W. \& CHILD, T. B. 2013. Changes to the ownership and control of East Asian corporations between 1996 and 2008: The primacy of politics. Journal of Financial Economics, 107, 494-513.

CHANG, W.-C. 2012. Eastern religions and attitude toward direct democracy in Taiwan. Politics and Religion, 5, 555-583. 
CHAVA, S., LIVDAN, D. \& PURNANANDAM, A. 2009. Do shareholder rights affect the cost of bank loans? Review of Financial Studies, 22, 2973-3004.

CHEN, H., HUANG, H. H., LOBO, G. J. \& WANG, C. 2016. Religiosity and the cost of debt. Journal of Banking and Finance, 70, 70-85.

CHEN, S., CHEN, X. \& CHENG, Q. 2008. Do family firms provide more or less voluntary disclosure? Journal of Accounting Research, 46, 499-536.

CHEN, T.-Y., DASGUPTA, S. \& YU, Y. 2014. Transparency and financing choices of family firms. Journal of Financial and Quantitative Analysis, 49, 381-408.

CHUA, J. H., CHRISMAN, J. J. \& SHARMA, P. 1999. Defining the family business by behavior. Entrepreneurship: Theory and Practice, 23, 19-19.

CHUI, A. C., KWOK, C. C. \& ZHOU, G. S. 2016. National culture and the cost of debt. Journal of Banking and Finance, 69, 1-19.

CLAESSENS, S., DJANKOV, S., FAN, J. P. \& LANG, L. H. 2002. Disentangling the incentive and entrenchment effects of large shareholdings. Journal of Finance, 57, 2741-2771.

CLAESSENS, S., DJANKOV, S. \& LANG, L. H. 2000. The separation of ownership and control in East Asian corporations. Journal of Financial Economics, 58, 81-112.

COHEN, A.B. \& VARNUM M.E. 2016. Beyond East vs. West: Social class, region, and religion as forms of culture. Current Opinion in Psychology, 8, 5-9.

CREMERS, K. M., NAIR, V. B. \& WEI, C. 2007. Governance mechanisms and bond prices. Review of Financial Studies, 20, 1359-1388.

CUCCULELLI, M., PERUZZI, V. \& ZAZZARO, A. 2019. Relational capital in lending relationships: Evidence from European family firms. Small Business Economics, 52, 277-301.

D'AURIZIO, L., OLIVIERO, T. \& ROMANO, L. 2015. Family firms, soft information and bank lending in a financial crisis. Journal of Corporate Finance, 33, 279-292.

DAWSON, A., PAEGLIS, I. \& BASU, N. 2018. Founder as Steward or Agent? A Study of Founder Ownership and Firm Value. Entrepreneurship Theory and Practice, 42, 886-910.

DE MASSIS, A., SHARMA, P., CHUA, J. H. \& CHRISMAN, J. J. 2012. Family business studies: An annotated bibliography, Edward Elgar Publishing.

DEHEJIA, R., DELEIRE, T. \& LUTTMER, E. F. 2007. Insuring consumption and happiness through religious organizations. Journal of Public Economics, 91, 259-279.

DEMIRGÜÇ-KUNT, A. \& LEVINE, R. 2004. Financial structure and economic growth: A cross-country comparison of banks, markets, and development, MIT Press.

DINH, T. Q. \& CALABRÒ, A. 2019. Asian family firms through corporate governance and institutions: A systematic review of the literature and agenda for future research. International Journal of Management Reviews, 21, $50-75$.

DJANKOV, S., LA PORTA, R., LOPEZ-DE-SILANES, F. \& SHLEIFER, A. 2008. The law and economics of selfdealing. Journal of Financial Economics, 88, 430-465.

DJANKOV, S., MCLIESH, C. \& SHLEIFER, A. 2007. Private credit in 129 countries. Journal of Financial Economics, 84, 299-329.

DURNEV, A. \& KIM, E. H. 2005. To steal or not to steal: Firm attributes, legal environment, and valuation. Journal of Finance, 60, 1461-1493.

ELLUL, A., GUNTAY, L. \& LEL, U. 2007. External governance and debt agency costs of family firms, Board of Governors of the Federal Reserve System, International Finance Discussion Papers, 908.

FACCIO, M. \& LANG, L. H. 2000. The separation of ownership and control: An analysis of ultimate ownership in Western European corporations, Working Paper.

FERRI, G. \& MURRO, P. 2015. Do firm-bank 'odd couples' exacerbate credit rationing? Journal of Financial Intermediation, 24, 231-251.

FRANCIS, B., HASAN, I., HUANG, Y. \& SHARMA, Z. 2012. Do banks value innovation? Evidence from US firms. Financial Management, 41, 159-185.

FRIEDMAN, E., JOHNSON, S. \& MITTON, T. 2003. Propping and tunneling. Journal of Comparative Economics, $31,732-750$.

FUKUYAMA, F. 1995. Trust: The social virtues and the creation of prosperity, Free Press.

GAO, H., HE, J., LI, Y. \& QU, Y. 2020. Family control and cost of debt: Evidence from China. Pacific-Basin Finance Journal, 60, 101286.

GILSON, R. J. 2005. Controlling shareholders and corporate governance: Complicating the comparative taxonomy. Harvard Law Review, 119, 1641. 
GODLEWSKI, C. J. 2020. How legal and institutional environments shape the private debt renegotiation process? Journal of Corporate Finance, 62, 101555.

GÓMEZ-MEJÍA, L. R., HAYNES, K. T., NÚÑEZ-NICKEL, M., JACOBSON, K. J. \& MOYANO-FUENTES, J. 2007. Socioemotional wealth and business risks in family-controlled firms: Evidence from Spanish olive oil mills. Administrative Science Quarterly, 52, 106-137.

GONZALEZ, M., GUZMAN A., PABLO E. \& TRUJILLO M.-A. 2019. Is board turnover driven by performance in family firms?. Research in International Business and Finance, 48, 169-186.

GOODE, W. J. 1963. World revolution and family patterns, Free Press.

GRAHAM, J. R., LI, S. \& QIU, J. 2008. Corporate misreporting and bank loan contracting. Journal of Financial Economics, 89, 44-61.

GRULlON, G., KANATAS, G. \& WESTON, J. 2009. Religion and corporate (mis) behavior. Working Paper.

GUISO, L. \& MINETTI, R. 2010. The structure of multiple credit relationships: Evidence from US firms. Journal of Money, Credit and Banking, 42, 1037-1071.

HERNÁNDEZ-LINARES, R., SARKAR, S. \& LÓPEZ-FERNÁNDEZ, M. C. 2017. How has the family fïm literature addressed its heterogeneity through classification systems? An integrated analysis. European Journal of Family Business, 7, 1-13.

HILARY, G. \& HUI, K. W. 2009. Does religion matter in corporate decision making in America? Journal of Financial Economics, 93, 455-473.

HOFFMANN, A. O. \& KLEIMEIER, S. 2019. Financial disclosure readability and innovative firms' cost of debt. International Review of Finance, 21, 699-713

JENSEN, M. C. \& MECKLING, W. H. 1976. Theory of the firm: Managerial behavior, agency costs and ownership structure. Journal of Financial Economics, 3, 305-360.

JIANG, F., JIANG, Z., KIM, K. A. \& ZHANG, M. 2015. Family-firm risk-taking: does religion matter? Journal of Corporate Finance, 33, 260-278.

JIANG, G., LEE, C. M. \& YUE, H. 2010. Tunneling through intercorporate loans: The China experience. Journal of Financial Economics, 98, 1-20.

JOHN, K., LYNCH, A. W. \& PURI, M. 2003. Credit ratings, collateral, and loan characteristics: Implications for yield. Journal of Business, 76, 371-409.

KIM, J. B., SIMUNIC, D. A., STEIN, M. T. \& YI, C. H. 2011. Voluntary audits and the cost of debt capital for privately held firms: Korean evidence. Contemporary Accounting Research, 28, 585-615.

LA PORTA, R., LOPEZ-DE-SILANES, F. \& SHLEIFER, A. 1999. Corporate ownership around the world. Journal of Finance, 54, 471-517.

LA PORTA, R. L., LOPEZ-DE-SILANE, F., SHLEIFER, A. \& VISHNY, R. W. 1996. Trust in large organizations. American Economic Review, 87, 333-338.

LA PORTA, R. L., LOPEZ-DE-SILANE, F., SHLEIFER, A. \& VISHNY, R. W. 1998. Law and finance. Journal of Political Economy, 106, 1113-1155.

LANG, M. H., LINS, K. V. \& MILLER, D. P. 2004. Concentrated control, analyst following, and valuation: Do analysts matter most when investors are protected least? Journal of Accounting Research, 42, 589-623.

LEE, Y.-J., PARISH, W. L. \& WILLIS, R. J. 1994. Sons, daughters, and intergenerational support in Taiwan. American Journal of Sociology, 99, 1010-1041.

LIN, C., MA, Y., MALATESTA, P. \& XUAN, Y. 2011. Ownership structure and the cost of corporate borrowing. Journal of Financial Economics, 100, 1-23.

LINS, K. V., VOLPIN, P. \& WAGNER, H. F. 2013. Does family control matter? International evidence from the 2008-2009 financial crisis. Review of Financial Studies, 26, 2583-2619.

LOZANO M.B. \& YAMAN S. 2020. The determinants of cash flow sensitivity of cash: The family ownership effect.

Research in International Business and Finance, 53, 101204.

MA, L., MA, S. \& TIAN, G. 2017. Corporate opacity and cost of debt for family firms. European Accounting Review, 26, 27-59.

MANSOUR, W., BEN JEDIDIA, K. \& MAJDOUB, J. 2015. How Ethical is Islamic Banking in the Light of the Objectives of Islamic Law? Journal of Religious Ethics, 43, 51-77.

MCGUIRE, S. T., OMER, T. C. \& SHARP, N. Y. 2012. The impact of religion on financial reporting irregularities. Accounting Review, 87, 645-673.

MILLER, A. S. \& HOFFMANN, J. P. 1995. Risk and religion: An explanation of gender differences in religiosity. Journal for the Scientific Study of Religion, 34, 63-75.

MURRO, P. \& PERUZZI, V. 2019. Family firms and access to credit. Is family ownership beneficial? Journal of Banking and Finance, 101, 173-187. 
MYERS, S. C. \& MAJLUF, N. S. 1984. Corporate financing and investment decisions when firms have information that investors do not have. Journal of Financial Economics, 13, 187-221.

NGUYEN, D. T. T., DIAZ-RAINEY, I., ROBERTS, H. \& LE, M. 2021. Loans from my neighbours: East Asian commercial banks, financial integration, and bank default risk. International Review of Financial Analysis, $74,101659$.

O'BOYLE, E. H., POLLACK, J. M. \& RUTHERFORD, M. W. 2012. Exploring the relation between family involvement and firms' financial performance: A meta-analysis of main and moderator effects. Journal of Business Venturing, 27, 1-18.

PÉREZ-GONZÁLEZ, F. 2006. Inherited control and firm performance. American Economic Review, 96, 1559-1588.

PETERSEN, M. A. \& RAJAN, R. G. 1994. The benefits of lending relationships: Evidence from small business data. Journal of Finance, 49, 3-37.

PRENCIPE, A., BAR-YOSEF, S. \& DEKKER, H. C. 2014. Accounting research in family firms: Theoretical and empirical challenges. European Accounting Review, 23, 361-385.

PUTNAM, R. 1993. Making democracy work: Civic traditions in modern Italy. Princeton University Press.

QIAN, J. \& STRAHAN, P. E. 2007. How laws and institutions shape financial contracts: The case of bank loans. Journal of Finance, 62, 2803-2834.

REHER, D. S. 2004. Family ties in western Europe in: Strong family and low fertility: A paradox? : Springer.

SHARMA, P. \& CHUA, J. H. 2013. Asian family enterprises and family business research. Asia Pacific Journal of Management, 30, 641-656.

SINCLAIR, A. 1993. Approaches to organisational culture and ethics. Journal of Business Ethics, 12, 63-73.

SOLEIMANOF, S., RUTHERFORD, M. W. \& WEBB, J. W. 2018. The intersection of family firms and institutional contexts: A review and agenda for future research. Family Business Review, 31, 32-53.

STEIER, L. 2001. Family firms, plural forms of governance, and the evolving role of trust. Family Business Review, 14, 353-368.

STEIER, L. P. 2009. Familial capitalism in global institutional contexts: Implications for corporate governance and entrepreneurship in East Asia. Asia Pacific Journal of Management, 26, 513-535.

STOCK, J. H. \& YOGO, M. 2005. Testing for weak instruments in linear IV regression. Identification and inference for econometric models: Essays in honor of Thomas Rothenberg, 80, 1.

STRAHAN, P. E. 1999. Borrower risk and the price and nonprice terms of bank loans. FRB of New York staff report 90.

SUNDARAMURTHY, C. 2008. Sustaining trust within family businesses. Family Business Review, 21, 89-102.

SWANPITAK, T., PAN, X. \& SUARDI, S. 2020. Family control and cost of debt: Evidence from Thailand. PacificBasin Finance Journal, 62, 101376.

THORNTON, P. H., OCASIO, W. \& LOUNSBURY, M. 2012. The institutional logics perspective: A new approach to culture, structure, and process, Oxford University Press.

The Asian Economic Integration Report, 2019-2020. Available at: https://aric.adb.org/pdf/aeir/AEIR20192020_complete.pdf (accessed 20 September 2021).

The Economist, 2015. To have and to hold. Special report. Available at: https://www.economist.com/specialreport/2015/04/16/to-have-and-to-hold (accessed 10 October 2020).

VAN BUREN III, H. J., SYED, J. \& MIR, R. 2020. Religion as a macro social force affecting business: Concepts, questions, and future research. Business \& Society, 59, 799-822.

VILLALONGA, B. \& AMIT, R. 2006. How do family ownership, control and management affect firm value? Journal of Financial Economics, 80, 385-417.

VITELL, S. J. 2009. The role of religiosity in business and consumer ethics: A review of the literature. Journal of Business Ethics, 90, 155-167.

WEAVER, G. R. \& AGLE, B. R. 2002. Religiosity and ethical behavior in organizations: A symbolic interactionist perspective. Academy of Management Review, 27, 77-97.

WOOLDRIDGE, J. M. 2010. Econometric analysis of cross section and panel data, MIT press.

ZHAO, E. Y. \& LOUNSBURY, M. 2016. An institutional logics approach to social entrepreneurship: Market logic, religious diversity, and resource acquisition by microfinance organizations. Journal of Business Venturing, 31, 643-662.

ZOU, H. \& ADAMS, M. B. 2008. Debt capacity, cost of debt, and corporate insurance. Journal of Financial and Quantitative Analysis, 43, 433-466. 